\title{
Comissões Permanentes, Estrutura de Assessoramento e o Problema Informacional na Câmara dos Deputados do Brasil*
}

\author{
Fabiano Santos ${ }^{1}$ \\ Júlio Canello ${ }^{1}$
}

1. Universidade do Estado do Rio de Janeiro (UERJ), Rio de Janeiro, RJ, Brasil. E-mail para contato: fsantos@iesp.uerj.br.

\section{INTRODUÇÃO}

$\mathrm{D}$ ebate travado entre dois importantes quadros da administração pública brasileira em meados da década dos 90 do século passado ilumina aspectos hoje essenciais para o entendimento do processo democrático no país ${ }^{1}$. De um lado, um dos principais assessores da liderança partidária do Partido da Social Democracia Brasileira (PSDB) no Senado Federal, Antonio Carlos Pojo do Rego, denunciava a "impossibilidade lógica" subjacente à estrutura institucional de assessoramen-

\footnotetext{
* A realização desta pesquisa contou com diversos apoios e parcerias. Agradecemos ao Conselho Nacional de Desenvolvimento Científico e Tecnológico (CNPq) e à Fundação Carlos Chagas Filho de Amparo à Pesquisa do Estado do Rio de Janeiro (Faperj), pelo fomento à pesquisa; à Secretaria-Geral da Câmara, bem como Assessoria da Liderança dos partidos e à Consultoria Legislativa pelo acesso aos dados e facilitar o contato com os servidores e técnicos depoentes na parte qualitativa da pesquisa; ao Instituto de Pesquisa Econômica Aplicada (Ipea), por debater uma primeira versão do trabalho no âmbito do Programa de Mobilização da Competência Nacional para Estudos sobre o Desenvolvimento (PROMOB). No âmbito deste projeto, agradecemos os comentários e críticas de Lucio Rennó, Manoel Leonardo Santos, Mathieu Turgeon e, sobretudo, Acir Almeida; e aos colegas da Sessão Temática "Estudos legislativos: avanços e perspectiva" da Associação Nacional de Pós-Graduação e Pesquisa em Ciências Sociais (Anpocs), em especial a Marta Mendes da Rocha, que comentou nosso trabalho e coordenou debates. Aos colegas da Diretoria de Estudos e Políticas do Estado, das Instituições e da Democracia (Diest/Ipea), também pela oportunidade de apresentar e debater uma das versões do artigo. Agradecimentos especiais, por fim, a Graziella Guiotti Testa pela competente assistência de pesquisa e aos entrevistados, profissionais da Câmara dos Deputados.
}

DADOS - Revista de Ciências Sociais, Rio de Janeiro, vol. 59, no-4, 2016, pp. 1127 a 1168. 
to do Legislativo, particularmente o da Câmara dos Deputados. Segundo o assessor do PSDB, o modelo adotado, centralizado na Mesa da Câmara e assumidamente burocrático, teria como base a existência de um corpo técnico neutro a serviço da qualidade das políticas públicas em discussão no Parlamento. A impossibilidade lógica adviria do fato desta concepção do serviço do assessor entrar em contradição com o papel eminentemente político/partidário do representante eleito, a quem aquele deve prestar contas em primeiro lugar. De outro lado, Mozart Paiva Vianna, Secretário-Geral da Mesa da Câmara dos Deputados durante mais de vinte anos, defendia aquele mesmo modelo, finalmente vitorioso, com base na ideia de que as exigências contemporâneas inerentes ao processo decisório demandam do Parlamento respostas ágeis e bem informadas sobre os mais diversos temas. Defendia, ademais, a perfeita compatibilidade entre o trabalho político dos representantes eleitos e o assessoramento de servidores altamente especializados e voltados para a qualidade da política pública. A vitória do modelo defendido por Vianna, na verdade, resultou na convivência de uma assessoria eminentemente política com uma assessoria, chamada na Câmara de Consultoria Legislativa (Conle), essencialmente técnica, cujos membros se percebem como especialistas e partidariamente neutros. Neste artigo, argumentamos que a evolução de tal tipo de assessoramento, isto é, a institucionalização de uma consultoria que se percebe e atua como neutra, pode ser entendida através da lógica informacional aplicada ao comportamento legislativo no Brasil.

A discussão é relevante, sobretudo porque as análises sobre processo decisório em políticas públicas no Brasil, logo após a promulgação da Carta de 1988, enfatizam, em geral, o que ocorre no interior do Poder Executivo. Quando envolvem o Legislativo, adotam tom predominantemente pessimista no sentido de que a interação entre os atores políticos não se dá em condições propícias à formulação e aprovação de uma agenda voltada para o enfrentamento de questões de interesse público mais amplo. Não obstante, e após intenso debate ocorrido ao longo da década dos 90 do século passado, a visão mais pessimista abriu passagem para uma perspectiva matizada na qual o Congresso Nacional torna-se um dos principais agentes no processo decisório de políticas públicas.

Contudo, ainda é quase consenso na literatura sobre o Legislativo no Brasil a percepção de que faltam regras e procedimentos capazes de incentivar o desenvolvimento de expertise e capacitação dos parlamenta- 
res para a formulação de políticas, de que o Congresso ainda estaria por desenvolver mecanismos informacionais no seu modo de atuar. $\mathrm{O}$ argumento a seguir postula que é possível detectar no interior da Câmara dos Deputados núcleos de excelência, a princípio capacitados ao exercício de funções de cunho informacional, a saber, suas comissões técnicas permanentes e a estrutura de assessoria da Câmara (destacando-se a Consultoria Legislativa). Este artigo analisa o segundo mecanismo e apresenta hipóteses sobre as condições em que o potencial informativo da assessoria é ativado, estabelecendo-se uma dinâmica informacional em seu modo de atuar.

O objetivo deste trabalho é, assim, oferecer algumas evidências em favor do argumento central, assim como de suas hipóteses específicas, revelando o potencial heurístico da linha de pesquisa proposta. Em primeiro lugar, promovemos breve descrição do principal órgão de produção endógena de expertise na Câmara dos Deputados: a Consultoria Legislativa, ou simplesmente Conle. Fica claro com tal descrição que a Conle não evolui de forma lenta e contínua, mas em saltos bem definidos ao longo do tempo, ocorrendo tais saltos em momentos cruciais de defesa do Congresso como instituição, em contraposição a um contexto externo desfavorável. Em segundo lugar, examinamos informações obtidas por meio de entrevistas semiestruturadas junto a consultores, assessores de partidos e funcionários ligados à diretoria da Mesa Diretora da Câmara para concluir que a Conle, embora centralizada e definida como órgão da Mesa, acaba sendo instrumento vital do trabalho informacional das comissões. Por último, analisamos alguns dados sobre atividade da Conle entre 2004 e 2011, período no qual o registro de pedidos e fluxo de informações do assessoramento legislativo foi realizado através do sistema Workflow. Em particular, comparamos a demanda de trabalho da Consultoria Legislativa e o volume da tramitação de projetos nas Comissões Permanentes da Câmara dos Deputados. É possível perceber alterações significativas na produção da Conle em anos de eleições gerais, bem como indicativos de maior demanda de trabalho por parte de comissões com perfil opositor ao governo, resultados consistentes com a perspectiva informacional.

Este artigo encontra-se estruturado em outras cinco seções. Em primeiro lugar, promovemos um balanço da literatura na área de estudos legislativos, apresentando os fundamentos da perspectiva informacional de análise de processos decisórios em órgãos colegiados, além de mostrar como ela pode ser útil para o entendimento da dinâmica parla- 
mentar no Brasil. Após um pequeno resumo da evolução histórica da Consultoria Legislativa da Câmara e da forma como ela se encontra atualmente organizada, apresentamos os objetivos básicos da pesquisa em desenvolvimento, a saber, analisar a estrutura de assessoramento da Câmara dos Deputados através da teoria informacional, ademais do argumento geral do trabalho, suas proposições centrais, bem como hipóteses específicas. As seções seguintes são dedicadas à aproximação empírica das proposições e hipóteses. De cunho qualitativo, a primeira analisa entrevistas semiestruturadas com assessores e consultores. Já a segunda examina dados agregados longitudinais sobre a produção de pareceres pela Conle e o volume de tramitação de projetos e pareceres nas Comissões Permanentes. Por fim, concluímos com um balanço geral da pesquisa e sua contribuição para o debate contemporâneo em torno dos problemas de representação e governabilidade no Brasil.

\section{FUNDAMENTOS INFORMACIONAIS DA ATIVIDADE LEGISLATIVA NA CÂMARA DOS DEPUTADOS}

Como largamente comentado na literatura da área, os estudos legislativos, precipuamente voltados para o caso do Congresso norte-americano, subdividem-se em três grandes perspectivas: a distributiva, a partidária e a informacional ${ }^{2}$. Para a presente análise, importa dedicar maior atenção à terceira abordagem. Em comum com a corrente partidária, a vertente informacional parte de uma crítica aos fundamentos e proposições centrais da perspectiva distributivista. De forma resumi$\mathrm{da}$, onde esta última observa particularismo, a primeira enxerga eficiência coletiva ${ }^{3}$. A organização do Congresso em torno de comissões, por exemplo, responderia antes à demanda dos parlamentares por $e x-$ pertise do que por distribuição de benefícios paroquiais - demanda que advém da tentativa de redução da incerteza que necessariamente ronda a formulação e implementação de políticas públicas.

A literatura sobre o Congresso brasileiro tem verificado a coexistência de elementos distributivos e partidários no comportamento legislativo de nossos parlamentares no atual período democrático ${ }^{4}$. Indicadores obtidos com base em pesquisas de opinião, produção legal, processo orçamentário e disciplina partidária revelam pelo menos dois pontos fundamentais: existe amplo reconhecimento sobre a importância de se constituir junto aos eleitores reputação pessoal, ou seja, a tarefa da representação política no Brasil está fortemente ancorada na figura indi- 
vidual do político; todavia, o espaço de atuação do representante tomado individualmente é reduzido no Parlamento, vale dizer, a atividade legislativa, sua organização e processo de decisão estão centralizados na liderança dos partidos, em particular, dos partidos que formam a base aliada ao governo ou a maioria parlamentar. Matérias de especial interesse do governo são, com frequência, enviadas diretamente para plenário por meio de instrumentos extraordinários de tramitação, como Medidas Provisórias e pedidos de urgência, desvalorizando o trabalho das comissões técnicas ${ }^{5}$. As oposições, por sua vez, também percebem o plenário como lugar de especial visibilidade na disputa, embora com menores chances de alteração efetiva na política pública, se comparado às comissões. No plenário, utilizam a verificação de votação e a obstrução como importantes recursos procedimentais que alteram as condições de barganha, podendo impor custos ao governo no encaminhamento da pauta legislativa e na acomodação de interesses de sua coalizão, especialmente em contextos de trancamento de pauta por Medidas Provisórias ${ }^{6}$. Desta forma, as políticas públicas advindas do Congresso teriam dupla marca e uma deficiência: embora alcancem o plenário de maneira condizente com a agenda consensual entre as lideranças dos partidos que compõem a coalizão de apoio ao Executivo (ou a maioria parlamentar), elas acabariam sendo também atingidas pela necessidade dos parlamentares de distribuir benefícios de natureza mais paroquial. A deficiência estaria relacionada ao escasso exame das proposições pelas comissões, antes de chegarem ao conjunto dos parlamentares para a tomada de decisão final.

Análises recentes, contudo, têm aplicado modelos informacionais a diversos aspectos da dinâmica congressual no Brasil, com resultados teóricos e empíricos relevantes ${ }^{7}$. Tais modelos partem de um cenário no qual o representante precisa escolher uma política pública $p$ e a tomada de decisão se dá sob condição de incerteza. A cada política $p$ está associado um resultado $x$, ambos usualmente definidos em um espaço unidimensional. Os legisladores, no entanto, não sabem a relação exata entre $p$ e $x$, mas apenas que para cada valor do primeiro existe uma distribuição de probabilidade de valores do segundo. A título de simplificação, defina-se a relação entre políticas e seus resultados de forma aditiva, como $x=p+\omega$, em que $\omega$ é um parâmetro cujo valor não é conhecido com certeza a priori ${ }^{8}$. De um ponto de vista substantivo, pode-se conceber $\omega$ como a expressão de fatores exógenos à decisão legislativa. 
O elemento decisivo e diferencial dessa perspectiva teórica é que o Legislativo pode adquirir informação sobre $\omega \mathrm{e}$, assim, reduzir a sua incerteza e a correspondente perda informacional, "consultando" atores que detenham informação sobre os efeitos da política ${ }^{9}$. Assume-se que, na dinâmica política brasileira, dois atores são fundamentais: o Executivo e o sistema de comissões técnicas do próprio Legislativo (doravante chamado apenas de comissão). Em geral, o Executivo é altamente informado sobre $\omega$, possuindo mais informação do que a comissão e o conjunto do Parlamento. Porém, o ponto de interesse é que a comissão tem meios para coletar informação relevante.

Devido à assimetria informacional entre o Executivo e o Legislativo, é esperado que o principal propositor de políticas públicas seja o primeiro e toda a vez que ele propõe uma política está, na verdade, fazendo uma recomendação ao segundo. A questão é saber em que condições o governo, ao propor uma política, compartilha toda a informação que possui sobre suas consequências ou, ao contrário, escamoteia subsídios essenciais para a tomada de decisão legislativa. De acordo com Santos e Almeida (2011), a decisão do Executivo de revelar informação depende do grau de congruência de interesses e preferências entre este e a inclinação majoritária no Legislativo em torno da política $p$. Em outras palavras, quanto maior a congruência entre as preferências do Executivo e da maioria do Parlamento em torno de $p$, menor a necessidade de este último recorrer à fonte alternativa - por exemplo, as comissões - de produção de dados para a obtenção de informação adicional. Portanto, nessas circunstâncias, menor será o papel informacional das comissões no processo de produção de políticas públicas. Por contraposição, em um cenário no qual o governo é o propositor de políticas, a existência de divergência significativa entre esse último e o conjunto dos legisladores é condição fundamental para que o sistema de comissões seja demandado a exercer o seu papel.

Santos e Almeida (2011) também procuraram estabelecer as condições sob as quais comissões permanentes teriam incentivos para agir dado o contexto institucional no qual se insere o Congresso brasileiro. Supondo haver alto grau de incerteza em torno da política $p$ por parte do Legislativo, mesmo após observar a recomendação do Executivo, aquele poderá se deparar com dois tipos distintos de comissão: uma de caráter mais "opositora" e outra de natureza mais "governista". Uma comissão é considerada "opositora" quando a maioria de seus membros possui visão oposta à do Executivo, dado o posicionamento majo- 
ritário do Parlamento em torno de uma política. Isto é, quando o Executivo estiver mais inclinado para uma das extremidades do espaço político vis-à-vis a tendência central do Legislativo em torno de $p$, uma comissão opositora estará posicionada na extremidade oposta vis-à-vis esta mesma tendência central. Caso contrário, a comissão é considerada "governista".

Comissões governistas não têm grandes motivos para produzir informação porque seus membros sabem que o Executivo tem incentivo para divulgar toda a informação que os beneficiem. Comissões opositoras, ao contrário, têm forte incentivo para produzir informação adicional e diferente da revelada pelo Executivo. O Legislativo, sabendo desse incentivo e interessado em reduzir a sua incerteza, fornece as condições para que a comissão exerça a sua função de agente informacional. Consequentemente, para o legislador, a comissão efetivamente informativa é a opositora - trata-se do único tipo de comissão que, pela natureza de seus participantes, é capaz de revelar informações estrategicamente omitidas pelo Executivo.

A conclusão a que se pode chegar, em sendo correto o raciocínio desenvolvido por Santos e Almeida (2011), é que o sistema de comissões permanentes do Legislativo possui papel informativo relevante no processo decisório em torno de políticas públicas. Este papel será tão mais acentuado quanto maior forem as divergências entre o Executivo e maiorias congressuais em torno do conjunto de políticas públicas apresentada pelo governo ao Legislativo, e quanto maior for o caráter oposicionista da comissão responsável pelo exame daquela política. Em outras palavras, o processo legislativo ordinário, quando apoiado por comissões cuja preferência mediana é oposta à do Executivo, permite ao plenário tomar uma decisão melhor informada e, assim, reduzir eventuais prejuízos decorrentes da sua desinformação.

Mesmo para o caso do Legislativo brasileiro, alguns resultados empíricos têm corroborado hipóteses que derivam dessa teoria. Medidas Provisórias e requerimentos de urgência em Projetos de Lei têm sido editados e aprovados em maior volume nas ocasiões em que as agendas do governo e da maioria legislativa são mais convergentes (Santos e Almeida, 2009 e 2011). A seleção de relatores na Câmara dos Deputados tem sido feita de acordo com a mesma lógica: relatores oposicionistas de projetos enviados pelo governo são mais frequentes quanto maior a distância entre o posicionamento do Executivo e do Legislati- 
vo (Santos e Almeida, 2005 e 2011). Em suma, há grande espaço para a investigação do uso que fazem os parlamentares brasileiros das instituições informacionais, existentes no interior do Parlamento.

Em debate com as indicações de Santos e Almeida (2011), as próximas seções serão dedicadas a avançar na aplicação da teoria informacional para o entendimento do funcionamento parlamentar no presidencialismo de coalizão brasileiro. Ou seja, embora trabalhos anteriores já tenham examinado alguns aspectos da atividade legislativa à luz dessa teoria, é razoável esperar que, sendo acertadas suas sugestões, outras instâncias e órgãos relevantes para o processo legislativo também possam ser mais bem entendidos quando utilizado esse tipo de modelo. Assim, nosso foco será exatamente o de especificar melhor o uso feito pelos órgãos internos de assessoramento parlamentar institucional em particular a Consultoria Legislativa da Câmara dos Deputados - no contexto decisório em torno de políticas públicas. Mostraremos, com maior ênfase, que o trabalho mais especializado e informacional da Consultoria junto às comissões depende de determinadas condições, encontrando-se em permanente tensão com as pressões oriundas dos incentivos distributivistas e partidários existentes na vida parlamentar em seu conjunto.

\section{ESTRUTURA DE ASSESSORIA DA CÂMARA DOS DEPUTADOS: HISTÓRICO, PROPOSIÇÃO GERAL E HIPÓTESES ESPECÍFICAS}

Suponha que o Executivo decida enviar um conjunto relevante de proposições, uma espécie de pacote de medidas envolvendo áreas sensíveis a diversos interesses e grupos sociais. Suponha que o governo esteja disposto a pedir urgência na tramitação dos projetos que compõem o pacote de políticas. Suponha ainda que o Congresso não se encontre inteiramente alinhado com o governo no que tange a diversos de seus aspectos. Seguindo a lógica da explicação informacional, os parlamentares reagirão à tentativa de uso pelo Executivo de mecanismos extraordinários de tramitação, de que são exemplos o da urgência e o das medidas provisórias, reação que tem no acionamento do sistema de comissões técnicas sua manifestação empírica e institucional mais evidente. Em outras palavras, o Congresso enviará os projetos para as comissões de natureza "opositora" e cujas especialidades são pertinentes às diversas faces do pacote, além de fornecer recursos e tempo para que as mesmas produzam informações adicionais e alter- 
nativas às que se encontrem na recomendação inicial de políticas feita pelo Executivo.

A partir da explicação informacional é possível formular duas questões-chaves sobre o papel do assessoramento legislativo técnico: 1) De que forma a Câmara dos Deputados está estruturada para fazer face ao desafio de levantar informações distintas das que já se encontram embutidas no pacote?; 2) De que maneira os legisladores seriam capazes de alterar as políticas propostas, no sentido de reduzir a incerteza em torno dos resultados esperados da decisão?

Nesse âmbito, dois sentidos podem ser conferidos ao conceito de assessoria parlamentar. $\mathrm{O}$ primeiro remete à noção administrativa de consecução de atividades por meio de uma organização. Tais atividades são vitais para o funcionamento rotineiro de uma instituição, auxiliando a realização de seus objetivos últimos. Desta noção deve-se apartar, pelo menos para fins de análise, a assessoria voltada para as chamadas funções de "natureza intelectual", vale dizer, a produção de alternativas para o processo decisório do Legislativo ${ }^{10}$, sentido empregado neste artigo. Ou seja, esta análise trata do assim chamado assessoramento institucional, que é endógeno, permanente, incidente tanto sobre a elaboração quanto sobre a tramitação de proposições, e que serve tanto aos parlamentares individualmente, quanto aos órgãos coletivos da Câmara, como comissões, lideranças partidárias e a secretaria-geral da Mesa (Paiva, 1995; Horta, 2011).

A estrutura administrativa da Câmara dos Deputados, no seu conjunto, isto é, envolvendo atividades meio e processo decisório, é bastante complexa (ver Tabela 1), englobando em torno de 13 mil funcionários, uma Diretoria-Geral, uma Secretaria-Geral, ligada à Mesa Diretora, e unidades subdivididas em mais cinco órgãos que se multiplicam, por sua vez, em mais catorze pequenos organismos. Do ponto de vista da inserção dos profissionais que trabalham no apoio à Casa, dois grandes grupos podem ser divisados. De um lado, os órgãos compostos por funcionários efetivos, como o Departamento de Comissões (Decom), cujas atribuições são basicamente de apoio às questões regimentais e de tramitação; as assessorias de lideranças partidárias; a Secretaria-Geral da Mesa Diretora; e as consultorias institucionais (Consultoria Legislativa - Conle; e a Consultoria do Orçamento), estas mais ligadas ao processo decisório substantivo. De outro, as assessorias contratadas temporariamente, de livre nomeação, por solicitação dos 
membros da Mesa Diretora, dos líderes partidários (os chamados Cargos de Natureza Especial - os CNEs) e dos parlamentares individualmente (o Secretariado Parlamentar).

Tabela 1

Pessoal da Câmara dos Deputados, por Tipo

(em 28/2/2015)

\begin{tabular}{l|r|r}
\hline Tipo & N & \multicolumn{1}{|c}{$\%$} \\
\hline Servidores efetivos & 3.425 & 25,7 \\
Cargos de natureza especial (livre provimento) & 1.349 & 10,1 \\
Secretariado parlamentar - sem vínculo & 8.259 & 62 \\
Secretariado parlamentar - requisitados & 299 & 2,2 \\
\hline Total & $\mathbf{1 3 . 3 3 2}$ & $\mathbf{1 0 0}$ \\
\hline
\end{tabular}

Fonte: Portal da Câmara dos Deputados.

Ainda pela tabela, observa-se que o secretariado parlamentar tem grande peso no conjunto da assessoria parlamentar (aproximadamente $62 \%$ do total de cargos). Contudo, os profissionais que compõem este segmento não possuem funções relacionadas ao exame de políticas públicas. São pessoas que trabalham no gabinete dos parlamentares e que ajudam a estruturar o papel de representante, num máximo de 25 assessores por deputado, respeitando a verba total, em 2015, de $\mathrm{R} \$ 78.000,00$ por deputado ${ }^{11}$. Aliás, de toda esta grande e complexa estrutura de apoio pode-se afirmar que a maior parte dedica-se a atividades de administração interna e de apoio aos mandatos. Os funcionários habilitados para a análise de políticas são basicamente os enquadrados na Assessoria de Lideranças e na Conle. Esta, pois, é considerada a estrutura de assessoria propriamente dita neste artigo.

Este sistema de produção e divulgação de informação especializada da Câmara dos Deputados, a chamada Conle, é fruto da Resolução 48 de 1993, por sua vez, consagrada no regimento interno desta Casa legislativa. Trata-se de poderosa máquina de análise e recomendação de políticas públicas. Atualmente dividida em 22 áreas de trabalho, é composta por um quadro técnico de mais de 250 cargos (não totalmente preenchidos), com grande parte dos servidores detentores de título de pós-graduação. O modelo seguido para a organização da assessoria especializada foi o centralizado, isto é, os funcionários especialistas, não obstante se subdividirem em diversas áreas, encontram-se todos alocados neste único órgão, responsável diretamente perante a Secretaria-Geral da Mesa. 
A Consultoria Legislativa da Câmara é relativamente recente, sobretudo se comparada ao órgão análogo no Senado Federal, criado em 1955. Na Câmara dos Deputados, as principais resoluções responsáveis pela criação da Consultoria foram fruto de estudo realizado pela Fundação Getulio Vargas, encomendado com vistas a um plano de reorganização dessa Casa ${ }^{12}$. Embora já existisse o cargo de assessor legislativo, com vagas a serem preenchidas por meio de concurso público, somente em 1971 foi criada a Seção de Assessoria Parlamentar e a Assessoria Técnica Especializada, subordinada ao Departamento de Comissões, com provimento de cargos sob a responsabilidade da Mesa Diretora. A sobreposição das atividades das duas assessorias, ambas incluídas no organograma da Câmara dos Deputados, conduziu à aprovação da Resolução no 52 / 1973, um segundo marco na criação de expertise na Câmara dos Deputados. Esta determinou a unificação das duas assessorias sob a rubrica de Assessoria Legislativa, subordinando-a diretamente à Diretoria Legislativa. O novo status adquirido na Casa levou à ampliação das atribuições e competências da Assessoria em seu conjunto, proporcionando aos profissionais atuações mais dinâmicas e produtivas junto aos parlamentares. Além disso, a centralização contribuiria para a legitimação do discurso e das atividades dos assessores especialistas.

O período da transição democrática traz pouca novidade no que diz respeito à institucionalização do modelo de assessoramento especializado. Novo e fundamental impulso somente surge, talvez não coincidentemente, em período de fragilidade e deslegitimação do Poder Legislativo: o que coincide com o escândalo dos anões do orçamento. Os principais partidos da Câmara naquele momento, Partido do Movimento Democrático Brasileiro (PMDB) e Partido da Frente Liberal (PFL), viram-se envolvidos em procedimentos heterodoxos de aprovação e realização de emendas ao orçamento da União. Quadros históricos destas agremiações, donos de grande experiência parlamentar e relevância no funcionamento da Casa, foram alvo de investigação e, ao final, acabaram sendo cassados. Tal crise se dá principalmente ao longo do ano de 1993, logo após o doloroso processo que resultou no impeachment do presidente Fernando Collor de Melo.

Com a Resolução 48, de 1993, o modelo centralizado torna-se parte do Regimento Interno da Câmara dos Deputados ${ }^{13}$. No mesmo período, grande número de vagas é criado, assim como é ampliada a quantidade de áreas a serem cobertas por profissionais especializados. Em 1998, o órgão ganha a denominação de Consultoria Legislativa e os profis- 
sionais, o título de consultores. Em 2001, foi criada a área de Previdência e Assistência Social e, em 2012, desmembrou-se uma área exclusiva para Direito Penal, Processo Penal e assuntos investigativos, assim permanecendo até hoje $\mathrm{e}^{14}$. Atualmente, a Consultoria da Câmara conta com 255 cargos, embora apenas 243 estejam efetivamente preenchidos ${ }^{15}$.

Em 2003, importante marco técnico foi conquistado com a digitalização do fluxo de demandas e entregas de trabalhos. Além da instalação do Workflow, nesse ano também ocorreu a criação do Conselho de Altos Estudos e Avaliação Tecnológica, composto por parlamentares, equipe interna de apoio administrativo e técnico, sendo seu secretário-executivo também diretor da Consultoria Legislativa. Pode-se dizer que a Conle adquire, neste momento, dinâmica própria, além de impulso endógeno de fortalecimento e legitimidade. Se no período de 1972-1990 a produção total de trabalhos situa-se na faixa de cem mil (subdivididos em $75 \%$ para elaboração legislativa, $15 \%$ para redação parlamentar e $10 \%$ para estudos e pesquisas), dados de 2011 apontavam para uma média de vinte mil trabalhos escritos por ano, no período de 2000 a 2010, chegando-se a uma projeção de 24 mil em $2011^{16}$.

Mas por que essa narrativa é compatível com a perspectiva informacional de organização legislativa? A vitória do modelo centralizado de assessoramento não foi algo pacífico. Setores influentes da própria estrutura de assessoria do Congresso apontavam para a existência de uma "impossibilidade lógica" subjacente ao modelo. Tais setores, do ponto de vista político, faziam eco às duas principais influências sobre o comportamento parlamentar no Brasil: àquela vinculada à necessidade de reprodução eleitoral dos deputados e àquela que emana das estruturas partidárias. Porém, grande parte dos assessores legislativos tem origem no procedimento de livre nomeação dos parlamentares, ou estão vinculados às lideranças partidárias. Portanto, a novidade trazida consiste justamente em revelar como evoluiu um modelo de assessoramento, atualmente concentrado na Conle, que responde às necessidades informacionais da Casa em seu conjunto. Neste sentido, vale a pena examinar algumas evidências atinentes à capacidade informativa da Conle em seu formato atual.

A Tabela 2 revela razoável investimento da Câmara dos Deputados na formação de seu pessoal vinculado ao exame de políticas públicas ${ }^{17}$. Em 2011, todo o conjunto dos membros da Conle possuía pelo menos diploma referente ao ensino superior completo. Quase 50\% destes 
completaram curso de pós-graduação stricto sensu (77 têm mestrado ou doutorado). Por outro lado, é esperado encontrar maior dispersão nos números da Decom e dos gabinetes de lideranças, segmentos que incluem vários tipos de profissionais, desde pessoal de apoio até agentes mais especializados em políticas públicas, no caso específico da assessoria partidária.

Tabela 2

Pessoal da Câmara dos Deputados Habilitado para Análise de Políticas Públicas, por Nível de Escolaridade e Lotação (em 31/8/2011)

\begin{tabular}{l|c|c|c|c|c|c}
\hline Escolaridade & \multicolumn{2}{|c|}{ Decom } & \multicolumn{2}{c|}{ Lideranças } & \multicolumn{2}{c}{ Conle } \\
\hline Doutorado completo & 0 & 0 & 1 & 0,3 & 23 & 14,0 \\
Mestrado completo & 18 & 5,9 & 14 & 4,7 & 54 & 32,9 \\
Especialização completa & 102 & 33,8 & 100 & 33,4 & 59 & 36,0 \\
Superior completo & 119 & 39,4 & 85 & 28,4 & 28 & 17,1 \\
Primeiro Grau completo & 7 & 2,3 & 13 & 4,3 & 0 & 0 \\
Segundo Grau completo & 39 & 12,9 & 44 & 14,7 & 0 & 0 \\
Sem registro & 17 & 5,6 & 42 & 14,0 & 0 & 0 \\
\hline Total & $\mathbf{3 0 2}$ & $\mathbf{1 0 0 , 0}$ & $\mathbf{2 9 9}$ & $\mathbf{1 0 0 , 0}$ & $\mathbf{1 6 4}$ & $\mathbf{1 0 0 , 0}$ \\
\hline
\end{tabular}

Fonte: Diretoria da Coordenação Administrativa (Consultoria Legislativa Câmara dos Deputados).

Uma leitura fria dos números não permite qualquer inferência segura a respeito do maior ou menor grau com que as comissões estão servidas por este conjunto de assessores. Embora não seja razoável esperar uma distribuição homogênea de especialistas por área ${ }^{18}$, uma conta simples indicaria que cada comissão permanente (existiam 20 no ano de referência dos dados) teria em média o apoio de algo em torno de 15 assessores (contando-se o total de profissionais alocados na Decom, isto é, 302). Não se trata de algo desprezível, considerando os números relativos a especialistas e mestres. Contudo, não são apenas as de natureza permanente que fazem o trabalho de analisar políticas em tramitação na Câmara. Boa parte da atividade legislativa passa pelas comissões especiais, temporárias, criadas para examinar projetos específicos. Além disso, no que é especialmente relevante para propósitos do argumento, a presença de assessores qualificados, que trabalham junto às lideranças dos partidos, também é de magnitude expressiva. Segundo o quadro de 2011, elas contavam com 299 assessores, dotados, em sua grande maioria, de diploma universitário, sendo um terço dos quais pelo menos especialistas. Mais importante ainda é a presença de grande contingente de doutores e mestres entre os qua- 
dros da Conle, mantendo-se a ressalva de uma provável distribuição não homogênea por áreas, com algo em torno de $40 \%$ de seus quadros possuindo diploma de pós-graduação stricto sensu. Certamente, é este o órgão interno mais apto a desenvolver o trabalho de produção de informação previsto pela teoria informacional aplicada ao caso do Legislativo brasileiro.

Desse quadro geral da estrutura administrativa da Câmara, e levando-se em conta a discussão teórica precedente, é possível elaborar duas proposições gerais e algumas hipóteses mais específicas. A primeira proposição é relativamente simples: a) a estrutura de assessoria da Câmara responde aos incentivos prevalecentes no quadro institucional e político que baliza o comportamento dos deputados federais. A literatura sobre o Legislativo no Brasil informa que elementos distributivos e partidários, e não propriamente informacionais, exercem forte pressão sobre a conduta dos parlamentares. É esperado que a estrutura de assessoria das casas congressuais responda a tais incentivos. A segunda proposição diz respeito à incidência do elemento informacional neste quadro mais amplo: b) em determinadas condições, os órgãos mais capacitados da assessoria (leia-se Conle) são acionados pelas comissões tendo em vista responder à demanda informacional do plenário.

A proposição (a) dá conta do contexto no qual se desenvolve a atividade parlamentar no Brasil e sugere um papel responsivo à estrutura de incentivos identificada na literatura: uma disputa entre tendências centrífugas, dada a natureza da competição eleitoral, e centrípetas, dado o quadro Constitucional de 1988 e o regimento interno da Câmara dos Deputados. Assim, verifica-se uma parte importante da assessoria baseada na livre nomeação dos parlamentares, e outra, bastante significativa, centralizada na Mesa Diretora. É relevante frisar que não existe uma estrutura de apoio específico ao sistema de comissões, órgão, como se viu, apto a desenvolver um trabalho informacional para o plenário. A Conle é uma instância de uma estrutura administrativa única que responde à Mesa Diretora. Nela, os consultores são organizados em um núcleo de pesquisa, à moda de um instituto ou departamento universitário. Pareceres, estudos e proposições são solicitados de maneira centralizada, à direção do órgão, solicitações distribuídas segundo a especialização e carga de trabalho de cada qual (Rego, 1995).

Não obstante, e aqui entra a proposição (b), o elemento informacional também está presente, uma vez verificadas as condições especificadas 
anteriormente, quais sejam, propostas de políticas suficientemente divergentes da preferência do legislador mediano, tempo hábil para produção de informações e comissões opositoras. Dadas tais condições, espera-se que o plenário acione as comissões que, por sua vez, buscarão apoio nos mecanismos internos para produção de informações sobre as políticas propostas. Em outras palavras, as comissões acabariam consumindo os serviços da estrutura de assessoria montada de maneira centralizada na Câmara, para desenvolver um trabalho de interesse coletivo da Casa.

O desenvolvimento de hipóteses mais específicas contribui para uma melhor definição das expectativas teóricas. Uma hipótese preliminar ou fundante - mais geral e que não será detalhada neste artigo - diz respeito à natureza da relação do Executivo com o mediano do Legislativo em torno de determinadas políticas. Pelo modelo informacional, o viés do presidente impacta positivamente na disposição da Câmara em examinar o projeto, evitando ritos extraordinários de tramitação e acionando as comissões bem como sua assessoria mais qualificada. Trata-se de sugestão examinada, para o caso brasileiro, por exemplo, no que diz respeito ao funcionamento das comissões permanentes e na utilização de pedidos de urgência para apreciação de projetos (Santos e Almeida, 2005, 2009 e 2011). Nessa perspectiva, seguindo debates e conclusões de outros estudos, seria possível sugerir que quanto maior for a distância entre as preferências do Executivo e do mediano do plenário, maior será a demanda pelo trabalho da Consultoria Legislativa, de forma geral ${ }^{19}$.

Igualmente relacionada com o modelo informacional, a primeira hipótese a ser enfrentada refere-se ao que podemos chamar de "paciência política" ${ }^{20}$. Examinar proposições demanda tempo, algo escasso em se tratando da vida parlamentar. A principal restrição da qual um representante é vítima diz respeito ao calendário eleitoral ${ }^{21}$. Assim, é razoável imaginar que a disposição para examinar matérias na comissão, acionando assessoria qualificada, diminua na medida em que as eleições se aproximem. Deste argumento, temos:

Hipótese 1: quanto mais próxima estiver uma eleição, menor será a demanda pelo trabalho da Consultoria Legislativa.

Já a segunda hipótese incide sobre a natureza da comissão, ligando-se à lógica informacional que perpassa a distância de preferências entre os diferentes órgãos colegiados (comissão $x$ plenário) e o Poder Execu- 
tivo. Ou seja, a noção de que o "viés" dos atores que propõem ou promovem determinada política incentiva o mediano do colegiado decisor à produção de informação alternativa não se aplica apenas ao plenário, mas também às comissões permanentes. Assim como o Legislativo tem mais razões para desconfiar de um Executivo distante de sua posição mediana, comissões opositoras também devem encontrar maiores motivações para verificar sinais e informações emitidos pelo governo. Nesse contexto, como sugerido pela literatura, espera-se que comissões oposicionistas sejam mais informativas do que as comissões governistas. Assim:

Hipótese 2: quanto mais oposicionista for uma comissão, maior será sua demanda pelo trabalho da Consultoria Legislativa para exame do mérito da proposição.

Uma vez sugeridas tais proposições gerais e hipóteses, as seções seguintes apresentam um quadro empírico exploratório, mas já importante para avaliar o alcance de uma teoria informacional quanto às estruturas de assessoramento parlamentar técnico na Câmara dos Deputados. Primeiro, examinamos os resultados de entrevistas semiestruturadas com assessores e consultores. Na sequência, com base em dados quantitativos disponíveis sobre o fluxo de trabalho da Conle e a produção legislativa nas Comissões Permanentes, buscamos avaliar evidências sobre a plausibilidade das duas hipóteses sugeridas em relação ao ciclo eleitoral e ao posicionamento político mediano da comissão.

Nesse sentido, as hipóteses sugeridas são avaliadas através de uma combinação de métodos qualitativos e quantitativos. Em primeiro lugar os resultados indicam que a Conle, embora centralizada e definida como órgão da Mesa, acaba sendo instrumento vital do trabalho informacional das entrevistas. Em seguida, promovemos alguns testes estatísticos com dados sobre a atividade da Conle entre 2004 e 2011, período no qual o registro de pedidos e fluxo de informações do assessoramento legislativo foi realizado através do sistema Workflow. Em particular, comparamos a demanda de trabalho da Consultoria Legislativa e o volume da tramitação de projetos nas Comissões Permanentes da Câmara dos Deputados. Constatamos alterações importantes na produção da Consultoria em anos de eleições gerais, bem como indicativos de maior demanda de trabalho por parte de comissões com perfil opositor ao governo. 


\section{ENTREVISTAS COM ASSESSORES E CONSULTORES PARLAMENTARES}

Esta seção tem por objetivo examinar os resultados de pesquisa qualitativa promovida com a aplicação de questionário aberto junto a assessores e consultores legislativos de alto nível de desempenho e responsabilidade no que tange à tramitação de matérias e proposições de políticas públicas na Câmara dos Deputados. A escolha por iniciar a pesquisa através de entrevistas tem sua justificativa. Por um lado, busca-se valorizar as falas dos próprios sujeitos envolvidos nas atividades de assessoramento como fonte relevante de informação. Por outro, começar a investigação com essa abordagem também permite detectar, nas narrativas desses sujeitos, quais elementos são verdadeiramente importantes no processo legislativo para, a partir disso, também identificar que tipos de dados podem ser examinados quantitativamente.

Foram selecionados dez entrevistados, assim categorizados: 2 funcionários da Secretaria-Geral da Mesa da Câmara ${ }^{22}$; 1 consultor legislativo especializado em assuntos constitucionais e que apoia a Comissão de Constituição, Justiça e Cidadania (CCJC) ${ }^{23} ; 1$ consultor legislativo especializado em temas tributários e financeiros e que acompanha os trabalhos da Comissão de Fiscalização Financeira e Controle $(\mathrm{CFFC})^{24}$; 1 consultor legislativo especializado em temas educacionais e que rotineiramente dá suporte à Comissão de Educação (CE); 1 consultor legislativo especializado em temas ligados à saúde e que atua junto à Comissão de Seguridade Social e Família (CSSF); 2 assessores de um grande partido de perfil de centro-direita (Democratas - DEM); e, 2 assessores de um grande partido de centro-esquerda (Partido dos Trabalhadores - PT).

O sistema de comissões da Câmara dos Deputados conta com diversos órgãos permanentes de avaliação de áreas substantivas de políticas públicas. Na área social, além da Comissão do Trabalho, e dos Direitos Humanos, destacam-se a da Educação e a Comissão de Seguridade Social e da Família, ambas escolhidas para entrevistas. Como a literatura especializada vem demonstrando (por exemplo, Figueiredo e Limongi, 1999), as comissões têm seu trabalho por vezes interrompido pelas lideranças partidárias, quando em coordenação com o Executivo, sendo os projetos que tramitam em seu interior enviados a plenário antes da votação do parecer dos relatores. Contudo, isto não significa que as comissões substantivas tenham sua relevância inteiramente 
cancelada ao longo do processo decisório. Várias emendas são comumente elaboradas em seu interior, além de audiências, testemunhos e debates em torno dos pontos mais polêmicos das diversas matérias. Tendo isso em conta, dois consultores foram selecionados para a entrevista com especialização nas áreas de influência de tais comissões, um na área de educação, outro na de saúde. Mas se os partidos, através de suas lideranças, são a instância principal de encaminhamento do processo decisório, sobretudo em torno das proposições de interesse do governo, então é necessário o exame de como seu corpo de suporte técnico, sua assessoria, enfim, desenvolve suas atividades.

O questionário base, do qual constam dez perguntas, procurou focar no processo de recepção de proposições e sua distribuição para instâncias ou indivíduos, tendo em vista produzir relatórios finais em torno de políticas. Visou, fundamentalmente, medir o grau de autonomia para o desenvolvimento do trabalho e as principais fontes de pressão externa. Pequenas variações foram feitas tendo em vista a natureza distinta dos entrevistados. E o que se esperou obter com a aplicação dos questionários? Basicamente, uma descrição do trabalho do assessor qualificado quando da tramitação de matérias que visem a alterações significativas no status quo legal do país. Em geral, a alteração da legislação é o início de qualquer processo decisório em políticas públicas, sobretudo aquelas cujo objetivo seja o de alterar determinadas condições sociais tidas como indesejáveis. Além disso, buscou-se detectar os constrangimentos externos que incidem sobre as atividades de tais assessores. Por último, interessa examinar as convergências e disparidades eventualmente existentes entre os diferentes assessores no que tange à natureza desses constrangimentos.

Como quadro geral emergente, destacam-se três pontos principais e consensuais entre os entrevistados: a) que o Legislativo, de fato, conta com desvantagens informacionais significativas relativamente ao Executivo no exame de políticas públicas; b) que o plano propriamente partidário e de pressões incide sobre o trabalho da Secretaria-Geral da Mesa e, naturalmente, na assessoria de lideranças dos partidos; e c) que embora a Consultoria Legislativa seja um órgão institucional da Câmara e de seus membros individuais, de fato seu trabalho acaba sendo quase que inteiramente dedicado às comissões. Além disso, como pontos mais específicos levantados na pesquisa, vale a pena registrar: 
a) Observou-se um consenso entre os entrevistados no sentido da superioridade técnica do Executivo e do papel fundamental que a assessoria, sobretudo a Conle, tem de reduzir e produzir algum equilíbrio informacional entre os poderes.

b) A segunda questão fundamental é a de se conhecer os critérios seguidos quando da decisão de enviar e retirar matérias relevantes para as comissões. Apreendemos do depoimento recolhido junto a membro qualificado da Secretaria-Geral que a definição se faz por critério técnico, seguindo orientação expressa no Regimento. Além disso, é relatado que a Presidência da Câmara, responsável pela decisão em última instância, costuma seguir as recomendações feitas pela assessoria. Contudo, pressões são feitas no sentido de se enviar as proposições em direção a comissões específicas, pressões advindas dos próprios presidentes de comissões permanentes, mas às vezes oriundas de grupos e frentes parlamentares. Quanto à retirada de projetos das comissões e envio para plenário ou para uma comissão temporária, não há qualquer injunção da parte dos assessores da Secretaria no que diz respeito à substância da matéria. A assessoria limita-se a informar sobre decurso de prazo e a recomendar adiamentos em ocasiões específicas. Há também recomendação nos casos de matérias complexas cujo conteúdo afete diretamente número maior do que três comissões permanentes.

c) Depoimento de entrevistados da Secretaria-Geral da Mesa revela que o trabalho de consolidação dos projetos que vão a voto em plenário é feito em consulta permanente com a Conle. Isto equivale a dizer que este órgão é um agente do conjunto da Casa e não propriamente de uma coalizão partidária que predomina em outras instâncias do Legislativo. Dúvidas sobre emendas a serem acolhidas, detalhes sobre a redação destas, bem como a direção e alcance das alterações aos projetos originais são esclarecidos por especialistas da Conle. Não é incomum que especialistas de áreas distintas sejam mobilizados a fim de esclarecer pontos pouco claros do processo de emendamento nas comissões, em plenário e sobre mudanças introduzidas quando da tramitação da proposição no Senado. Nestes casos, não raro, verdadeiras disputas epistemológicas ocorrem entre especialistas de distintas áreas, contrapondo, por exemplo, experts em meio ambiente a experts em agronegócio.

d) O relato da consultora que trabalha em área próxima da atuação da Comissão de Constituição, Justiça e Cidadania traz os seguintes pontos fundamentais: 1) qualquer parlamentar pode a qualquer 
tempo solicitar auxílio para os consultores (sobretudo para a elaboração de votos em separado, mas também no acompanhamento de debates e votações) e não apenas relatores das matérias em tramitação; 2) a maior parte da demanda, contudo, advém dos relatores; 3 ) a orientação do trabalho do consultor é eminentemente técnica, autônoma, extraída basicamente de seus próprios estudos, não havendo consulta a agentes externos; 4 ) o ritmo de resposta do trabalho dos consultores é ditado pelos parlamentares solicitantes.

e) Os consultores pertencentes às áreas substantivas de políticas públicas acrescentam aos depoimentos anteriores os seguintes pontos: 1) essencialmente, o trabalho do consultor incide sobre a elaboração de pareceres, mas emendas sobre projetos indo a voto também são solicitadas; 2) há, nas ocasiões em que ocorre escassez de tempo e excesso de demanda, uma ordem de prioridades no trabalho de consultores. Por exemplo, projetos em regime de urgência (a espera de parecer em plenário), além de projetos de maior abrangência (como os que tramitam em comissões especiais), acabam recebendo prioridade; 3 ) os consultores sugerem ouvir a opinião de grupos externos mediante a instalação de audiências públicas; 4) acordo de lideranças e aprovações de regime de urgência acabam alterando o ritmo de avaliação dos projetos.

f) Os assessores de lideranças apresentaram quadro bastante distinto do verificado na fala do consultor. Os seguintes pontos merecem destaque: 1) a Assessoria Técnica de Bancadas, como é chamada, emite pareceres e propõe emendas sobre, prioritariamente, as matérias mais importantes constantes das pautas, sendo o grau de importância um critério estabelecido pelas lideranças. No caso do DEM, por exemplo, prioridade total era conferida às medidas provisórias em tramitação; 2) é comum o recurso a atores externos ao Legislativo, como Organizações não governamentais (ONGs), órgãos da imprensa, grupos de interesse e movimentos sociais. Este ponto é especialmente relevante, pois os consultores da Conle, ao contrário dos assessores de partidos, não mencionam a questão eleitoral ou de clientelas de apoio como fator interveniente em seu trabalho, ao passo que esta é, em alguns momentos, a consideração mais importante dos assessores partidários; 3 ) os assessores de lideranças não são passivos como é a característica principal do trabalho dos consultores, a saber, agir acionado por demanda. Os partidos impõem aos assessores que busquem relatores membros das 
bancadas para expor a base técnica do posicionamento do partido sobre proposições específicas.

Como resultado das entrevistas, é relevante ressaltar o apoio fornecido às duas hipóteses centrais derivadas da teoria informacional aplicada ao funcionamento do Legislativo brasileiro. Em primeiro lugar, a vantagem informacional do Executivo foi enfatizada pelos entrevistados diretamente envolvidos com as propostas de políticas públicas em tramitação no Legislativo, da qual decorrem pressões partidárias significativas sobre o trabalho das comissões e da Consultoria Legislativa (Conle). Em segundo, e por outro lado, a estrutura montada no âmbito deste órgão central, com grande parte de seus quadros possuidores de diplomas de pós-graduação, confere à Câmara dos Deputados algum grau de expertise para a geração endógena de informação. E esta é exatamente a essência do trabalho destes assessores, segundo seu próprio depoimento.

Evidências iniciais em favor das hipóteses empíricas mais específicas também restaram disponíveis. Sabemos que a Conle foi estruturada para servir à demanda dos parlamentares, individual ou coletivamente. Assim, é válido questionar se as comissões seriam beneficiadas pelo trabalho dos consultores e se, na verdade, não acabariam sendo mais expressão da necessidade dos representantes de se especializarem na distribuição de benefícios em favor de regiões e grupos mais restritos. Não foi esse o quadro, todavia, que surgiu do depoimento dos consultores ouvidos nesta etapa qualitativa da análise empírica. Segundo estes, embora o trabalho da Conle possa a qualquer momento ser requerido por parlamentares que têm interesse na produção de emendas, é o acompanhamento de relatores na formulação de pareceres o que caracteriza o dia a dia de sua operação.

Em claro contraste com o trabalho de assessores das lideranças partidárias, que é o de buscar subsídios que aumentem a eficiência das estratégias do partido em seu embate político na Câmara, o trabalho dos consultores é o de gerar informações, hard data, na confecção de pareceres a serem apreciados nas comissões. Trabalho este que é feito de forma autônoma, com exceção de consulta a especialistas contatados para exporem seu conhecimento em audiências públicas. Na próxima seção, a partir dos elementos oferecidos pelas entrevistas e considerando dados quantificáveis disponibilizados pela Conle, realizaremos testes mais específicos em busca de evidências relativas às nossas hipóteses. 


\section{DEMANDA À CONLE, CICLOS ELEITORAIS E COMISSÕES OPOSITORAS}

A seção "Estrutura de Assessoria da Câmara dos Deputados: Histórico, Proposição Geral e Hipóteses Específicas" apresentou proposições gerais e hipóteses mais específicas sobre a estrutura e a demanda de trabalho da Consultoria Legislativa da Câmara dos Deputados. Tais hipóteses estão baseadas em assertivas teóricas da perspectiva informacional no que tange ao funcionamento do Legislativo brasileiro. Esta seção discute alguns resultados empíricos quantitativos relativos a elas. Mais do que promover testes sistemáticos e robustos, a pretensão deste artigo é indicar que as proposições informacionais não podem ser rejeitadas de plano, merecendo atenção teórica e maior aprofundamento empírico, constituindo uma faceta ainda pouco explorada na agenda de pesquisa sobre o funcionamento da Câmara dos Deputados.

Para iniciar o exame dos incentivos informacionais à demanda de trabalho da Conle pela Câmara dos Deputados, especialmente por suas comissões, analisamos dados fornecidos pela própria Consultoria, extraídos do sistema de Workflow, implantado em 2004 e substituído, no final de 2014, pelo SisConle (Sistema de Solicitações e Acompanhamento de Trabalhos da Consultoria Legislativa). Tais ferramentas permitem o monitoramento geral das atividades dessa instância de assessoria técnica.

Especificamente, as informações obtidas para este artigo referem-se ao quantitativo de proposições e pareceres elaborados pela Consultoria entre 2004 e 2011, agregados por área de atuação, bem como ao quantitativo de projetos que foram apreciados pelas Comissões Permanentes da Câmara dos Deputados. Assim, além dos dados extraídos do Workflow, os indicadores ligados ao processo legislativo também têm como fonte o Sistema de Informação Legislativa (Sileg). Embora o interesse de fundo deste trabalho seja o papel da Conle na produção endógena de informações para o processo legislativo em termos gerais, a estratégia quantitativa de análise percebe no acionamento da Consultoria junto às comissões permanentes (trabalhos técnicos em projetos e pareceres) um importante referente empírico desse processo, passível de mensuração e com variação suficiente, permitindo comparações, ao longo do tempo e entre diferentes áreas temáticas, complementando, assim, os elementos presentes nas entrevistas. 
De qualquer modo, tais dados apresentam algumas limitações importantes. Especialmente, a informação disponibilizada sobre pareceres da Conle não discrimina quantos desses trabalhos foram efetuados em relação a proposições que tramitam nas Comissões Permanentes, nem quantos deles foram ofertados às comissões especiais, temporárias ou diretamente ao plenário. Ou seja, embora os dados revelem o número de pareceres em projetos de lei emitidos pela Conle em cada uma de suas áreas, não há informação expressa e segura sobre esse mesmo número no âmbito de cada comissão.

Para possibilitar uma comparação entre informações de origens diferentes, permitindo uma estimativa rudimentar - uma proxy - do quantitativo de pareceres da consultoria relacionados a cada comissão, as Áreas de Assessoramento foram pareadas às Comissões Permanentes que apresentam equivalência temática ${ }^{25}$. A escolha por tal abordagem decorre das informações obtidas na etapa qualitativa da pesquisa, em especial, a praxe revelada pelos próprios Consultores Legislativos da atuação, de fato, no assessoramento das comissões cujos temas são mais afeitos às suas especialidades. Desse modo, o número de pareceres da Conle nas comissões representa o total, para cada ano, de pareceres do conjunto de áreas temáticas relacionado a cada uma dessas comissões ${ }^{26}$.

Finalmente, não se descartam eventuais inconsistências no próprio material disponibilizado aos pesquisadores, uma vez que não foi possível realizar um acesso primário aos dados individualizados. Ou seja, o exame empírico das hipóteses e o tratamento dos dados encontram claras limitações na forma de agregação (anual), no tamanho da série temporal (2004-2011) e na ausência de informações precisas sobre os pareceres da Consultoria no âmbito exclusivo das comissões. De todo modo, com base nesses instrumentos, é possível fazer uma aproximação às hipóteses que dizem respeito 1) aos impactos do período eleitoral na demanda da Conle, expressando a ideia de "impaciência política"; e 2) à maior utilização da estrutura de assessoria por comissões "opositoras", aquelas que potencialmente oferecem maiores ganhos informacionais ao plenário na medida em que agregam informação distinta daquela já ofertada pelo Executivo.

O Gráfico 1 descreve a evolução anual de pareceres emitidos pela Conle, entre 2004 e 2011. A linha sólida mostra o quantitativo total, enquanto a linha tracejada apresenta apenas o número de pareceres rela- 


\section{Gráfico 1}

Pareceres Emitidos pela Conle em Projetos de Lei (2004-2011)

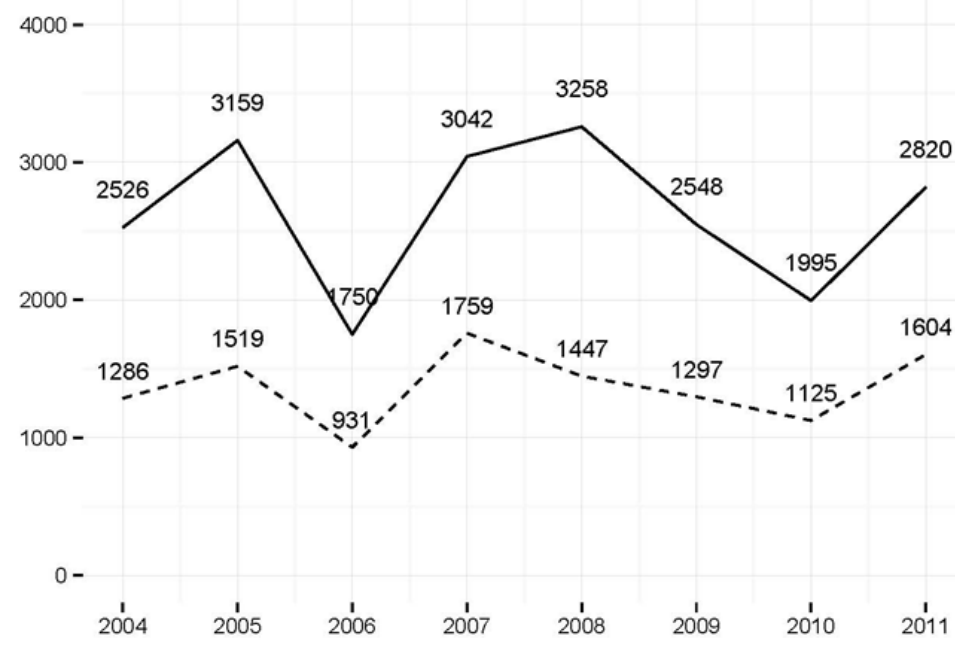

Fonte: Diretoria da Coordenação Administrativa (Consultoria Legislativa Câmara dos Deputados). Nota: A linha contínua apresenta os valores totais de pareceres emitidos, enquanto a linha tracejada conta as áreas de assessoramento relativas a políticas públicas.

tivos a áreas de políticas públicas. Pela hipótese 1, quanto mais próxima estiver uma eleição, menor será a demanda pelo trabalho da Consultoria Legislativa. Sua rationale remete ao fator custo de tempo, ou simplesmente à pressa com que os parlamentares querem ver proposições revertidas em políticas. Acionar a consultoria legislativa implica tempo investido no exame da matéria. A espera pela produção de informações e a deliberação em torno de propostas alternativas pode ser insuportável do ponto de vista político. Perdas distributivas e informacionais, no sentido de decisões mais afastadas do que seria possível ou de um nível maior de incerteza sobre os resultados, caso o plenário estivesse mais bem informado, são absorvidas em nome da necessidade de decidir. Este parece ser o caso dos anos eleitorais de 2006 e 2010.

Tanto no que concerne ao número global de pareceres emitidos, quanto às áreas mais substantivas, a diferença entre o fluxo de informações verificado nas comissões em anos pré e pós-eleições é significativa. Ao isolar do quadro geral das áreas de atuação apenas aquelas que tratam de políticas públicas substantivas - excluindo o conjunto voltado para o Direito e que apoiam, sobretudo, a Comissão de Constituição Justiça e Cidadania, as áreas que se dedicam à política externa, de defesa e se- 
gurança nacional, por conta de seu baixo impacto no âmbito interno, e a de assuntos político institucionais, por conta do seu diminuto apelo eleitoral - o contraste entre os anos eleitorais e os outros períodos é igualmente visível.

Resultados mais conclusivos dependem da ponderação pelo fluxo de proposições relativas às diferentes áreas. Caso haja uma queda na quantidade de projetos sob exame, proporcional à diminuição de pareceres emitidos, não poderemos mais distinguir se as eleições agem no sentido de se aumentar a pressa na tramitação de proposições e, por isso, a redução na demanda por expertise, preferindo-se mais delegação ao Executivo e mais recurso a assessoramento externo, ou se os pleitos eleitorais causam impacto no sentido de uma redução geral na atividade parlamentar, o que poderia confirmar apenas a hipótese do custo de oportunidade.

Antes mesmo de efetuar o pareamento entre as áreas de Assessoramento Legislativo e o âmbito de atuação das Comissões Permanentes, utilizando apenas os dados agregados por ano, é possível oferecer indicativos em apoio à hipótese informacional. Nesse sentido, o Gráfico 2 aponta que não apenas o número de pareceres cai nos anos eleitorais, como a razão entre pareceres da Consultoria e projetos de lei apreciados em comissões fica reduzida. Ou seja, nos períodos de proporção menor, a queda na demanda de trabalho da Conle supera a própria desaceleração do fluxo legislativo das comissões.

Nesse mesmo gráfico, a linha tracejada representa o valor mediano da taxa de governismo do plenário, na escala de 0 a 1 . Note que, além dos pontos mais baixos da razão entre pareceres/projetos corresponderem, em alguma medida, aos anos eleitorais, os picos em tal indicador associam-se aos anos em que a Câmara encontra-se mais oposicionista, 2005 e 2008. Ou seja, embora o nível de agregação e a diversidade de origem dos dados tragam algum ruído para a análise, é possível detectar uma tênue relação entre o nível de atividade da Consultoria e o posicionamento da Casa em face da agenda do governo.

Outra maneira de observar a desproporcionalidade da demanda de trabalho da Conle relativamente ao volume de atividade legislativa das Comissões é comparar as taxas de aumento ou diminuição dos pareceres vis-à-vis os projetos apreciados. Aqui, a expectativa é que a diminuição na taxa de confecção de pareceres em anos eleitorais supere a diminuição na quantidade de projetos, invertendo-se os resultados 


\section{Gráfico 2}

Razão entre Pareceres da Consultoria Legislativa e Projetos Apreciados em Comissões Permanentes (2004-2011)

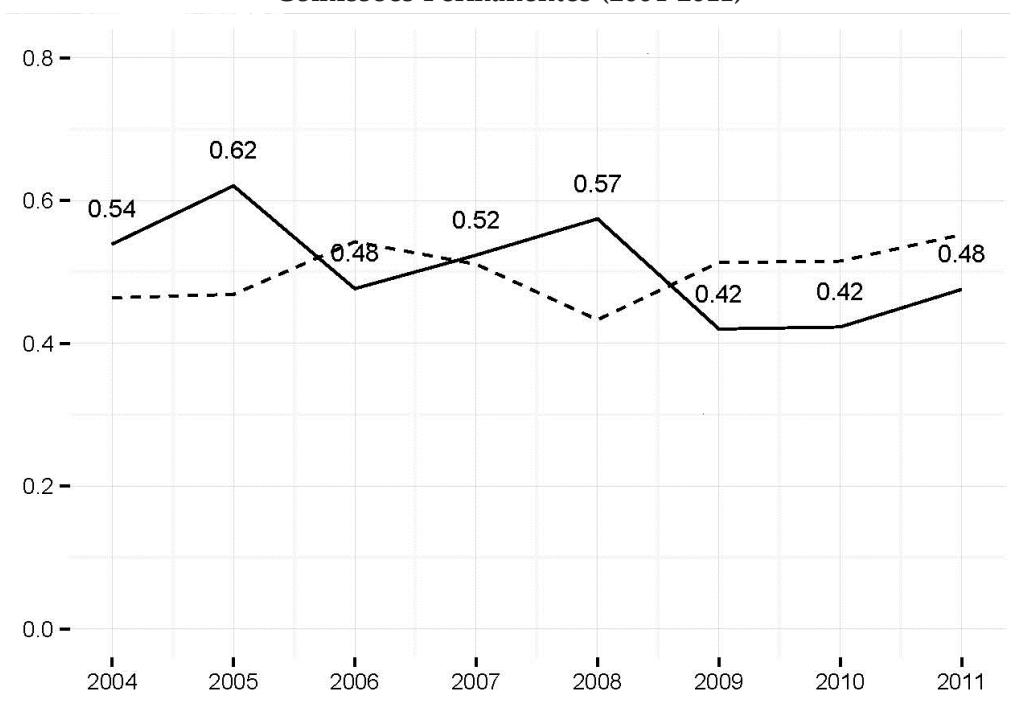

Fonte: Diretoria da Coordenação Administrativa (Consultoria Legislativa Câmara dos Deputados) e Centro de Documentação e Informação.

Nota: A linha contínua mostra a razão entre Pareceres da Consultoria Legislativa sobre o número de Projetos de Lei apreciados em Comissões Permanentes por ano. A linha tracejada aponta a taxa de governismo do plenário por ano, na escala de 0 a 1.

para os anos não eleitorais. O Gráfico 3 indica que tal proposição não pode ser simplesmente rejeitada.

De modo geral, embora o material empírico disponível não forneça resultados robustos, é possível observar, no período examinado, uma provável influência negativa do período eleitoral na demanda por trabalho de assessoramento legislativo da Conle, decréscimo este que supera a própria diminuição das atividades gerais da Câmara dos Deputados e suas Comissões Permanentes. Ou seja, o indicativo não é que o trabalho de assessoramento técnico diminui porque menos projetos tramitam, mas também porque a produção endógena de informação legislativa relevante deve envolver custos e tempos incompatíveis com os períodos eleitorais, conclusões em apoio ao papel - e a rationale - informacional da Conle.

A dificuldade em compatibilizar as áreas temáticas da Consultoria com as Comissões também inviabiliza uma conclusão definitiva sobre a hipótese 2, qual seja, sobre os efeitos das comissões opositoras. A par- 


\section{Gráfico 3}

Variação na Proporção de Pareceres da Consultoria Legislativa/Projetos Apreciados em Comissões Permanentes (2004-2011)

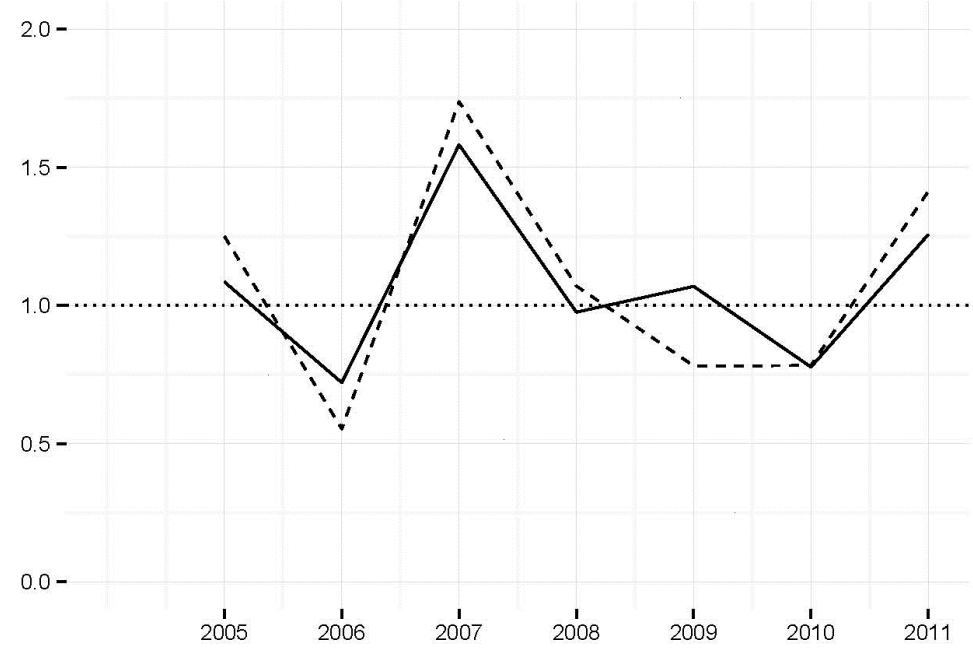

Fonte: Diretoria da Coordenação Administrativa (Consultoria Legislativa Câmara dos Deputados) e Centro de Documentação e Informação.

Nota: A linha contínua indica a taxa de variação anual no número de Projetos de Lei em Comissões, enquanto a linha tracejada denota a taxa de variação anual na emissão de Pareceres da Consultoria Legislativa. Valores abaixo de um representam diminuição no volume de trabalho, enquanto valores acima mostram aumento de produção.

tir da rationale informacional apresentada, sugeriu-se que comissões opositoras apresentam, potencialmente, maiores ganhos de informação ao plenário do que comissões que estejam mais alinhadas ao governo. Isso porque são os oposicionistas que possuem incentivos para produzir e revelar informação contrastante aos sinais do Executivo. Consequentemente, seriam precisamente estas comissões que demandariam mais o trabalho técnico da Consultoria ${ }^{27}$. Numa primeira abordagem, mais agregada, para a Casa como um todo, o Gráfico 2 mostra-se sugestivo no sentido da hipótese formulada.

Para examinar melhor tal sugestão, ainda que de maneira exploratória, classificamos o perfil de cada Comissão permanente como "governista" ou "opositora", nos anos entre 2004 e 2011, com base na mediana de governismo ${ }^{28}$ de seus membros titulares. Comissões cujo indicador foi inferior a $50 \%$ foram classificadas como opositoras. A Tabela 3 apresenta a quantidade média anual de Projetos de Lei apreciados e de pareceres da Conle em Projetos de Lei segundo o tipo de comissão, tendo a comissão-ano como unidade de observação $(\mathrm{N}=144)$. 
Fabiano Santos e Júlio Canello

Tabela 3

Média de Projetos de Lei e de Pareceres da Conle em Projetos de Lei por Tipo de Comissão (2004-2011)

\begin{tabular}{l|c|c}
\hline & PLs & Pareceres \\
\hline Governista & 280 & 166 \\
Opositora & 310 & 179 \\
\hline
\end{tabular}

Fonte: Diretoria da Coordenação Administrativa (Consultoria Legislativa Câmara dos Deputados), Centro de Documentação e Informação.

Apesar do nível amplo de agregação dos dados, observa-se que a média de Projetos e Pareceres é maior nas comissões opositoras. Todavia, tais diferenças de médias não são estatisticamente significativas. Mesmo assim, essa informação inclina-se no sentido da hipótese sugerida, de que comissões opositoras recorrem mais vezes à assessoria técnica da Câmara dos Deputados para produzir informação.

Uma análise mais desagregada desses dados, observando a taxa de governismo da comissão e não apenas sua classificação binária, oferece informações adicionais. Do ponto de vista gráfico, não há indicativo de associação entre o nível de apoio ao governo das comissões e a tramitação de projetos ou elaboração de pareceres da Consultoria. O exemplo do número de projetos de lei mostra uma reta de regressão com pouquíssima inclinação, bem como a existência de importantes pontos outliers, situados na CCJC, que apresentam contagem elevada no número de PLs (Gráfico 4).

Testes econométricos adicionais podem auxiliar na identificação de possíveis associações entre o nível de governismo da comissão, o volume de seu trabalho legislativo e sua demanda por assessoramento técnico ${ }^{29}$. Uma primeira abordagem é simplesmente relacionar a contagem dos indicadores de atividade legislativa (PLs e pareceres) com a taxa de governismo. Porém, é razoável esperar que o ambiente geral da Casa nos diferentes anos seja interveniente nos resultados, recomendando a utilização de efeitos fixos para a dimensão temporal. De modo análogo, a especialidade temática de cada comissão permanente também pode afetar o fluxo de trabalho, com áreas eventualmente afeitas a assuntos mais complexos ou mais solicitados, inclusive por força de disposições regimentais da Câmara dos Deputados. O exemplo da CCJC é o mais saliente. Praticamente todos os projetos legislativos, de diferentes matérias, passam pelo crivo dessa comissão, que examina sua constituciona- 
Comissões Permanentes, Estrutura de Assessoramento e o Problema...

\section{Gráfico 4}

Gráfico de Dispersão. Governismo x Projetos apreciados em Comissões Permanentes

(2004-2011)

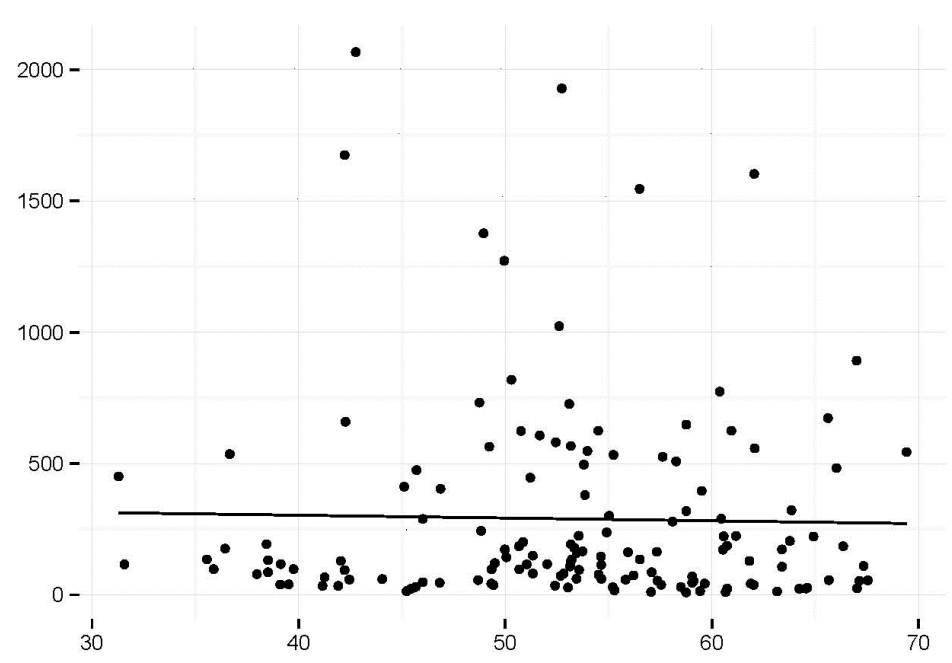

Fonte: Diretoria da Coordenação Administrativa (Consultoria Legislativa Câmara dos Deputados) e Centro de Documentação e Informação.

Nota: O gráfico de dispersão relaciona a taxa de governismo (eixo x) ao número de Projetos de Lei em Comissões (eixo y) tendo como unidade de observação a comissão-ano ( $\mathrm{N}=144)$. Inclui reta de regressão simples.

lidade e juridicidade. Esse fator, por sua vez, também explica em boa parte seu comportamento outlier, nítido no Gráfico 4.

Nessa perspectiva, foram estimados modelos de regressão binomial negativa, próprios para dados de contagem com sobredispersão, primeiro apenas com o governismo como variável dependente, depois com a inclusão de efeitos fixos para anos e comissões ${ }^{30}$. Para visualizar as possíveis diferenças substantivas do governismo no volume de trabalho das Comissões e Consultoria, optamos por estimar as contagens esperadas das variáveis dependentes para diferentes níveis de governismo. O Gráfico 5 apresenta as distribuições das frequências esperadas para os PLs e Pareceres, obtidas através de simulações dos parâmetros estimados, comparando uma região oposicionista a outra governista.

A figura mostra sinais em favor da plausibilidade da hipótese relativa ao posicionamento da comissão, uma ideia fundada nas sugestões teóricas indicadas na seção "Fundamentos Informacionais da Atividade 


\section{Gráfico 5}

Resultados das Simulações. Densidade das Contagens Esperadas. Projetos de Lei e Pareceres da Consultoria Legislativa
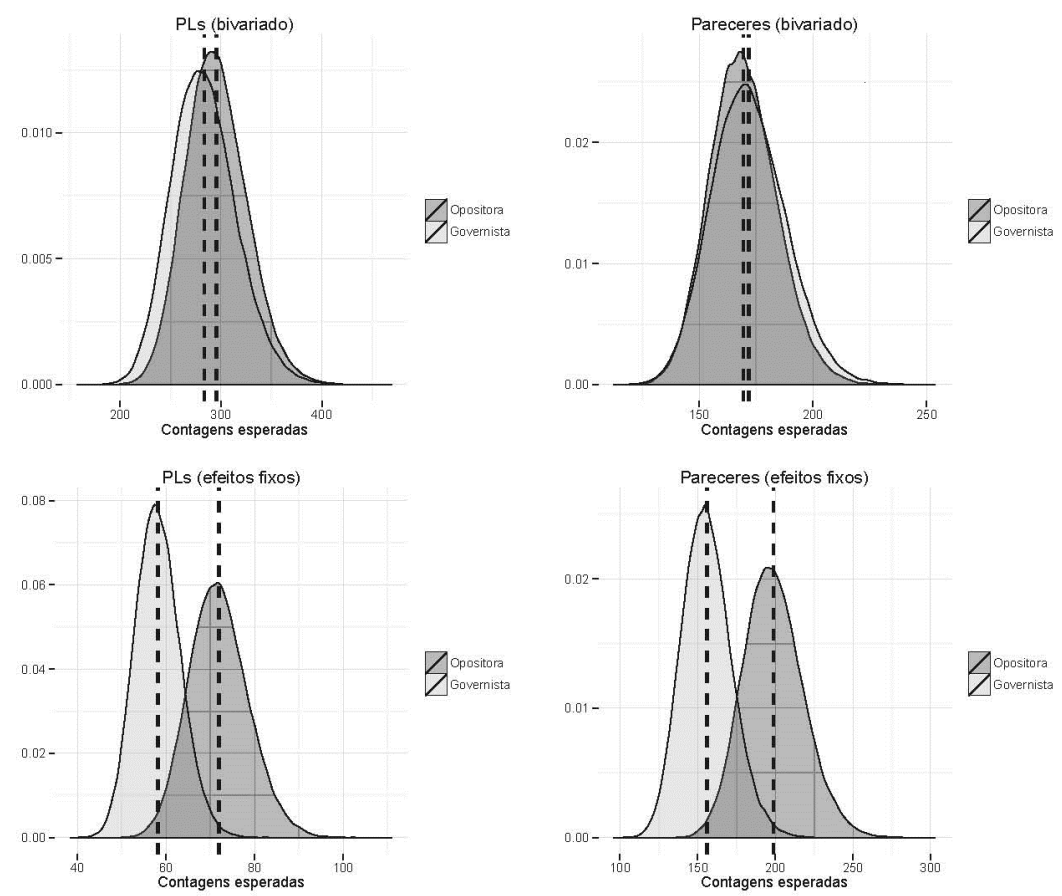

Fonte: Diretoria da Coordenação Administrativa (Consultoria Legislativa Câmara dos Deputados), Centro de Documentação e Informação.

Nota: A figura apresenta quatro gráficos de densidade das distribuições das contagens esperadas. Para levar em conta a incerteza fundamental sobre o componente estocástico dos modelos de regressão binomial negativa, foram rodadas 100.000 simulações a partir dos parâmetros estimados e calculadas as respectivas distribuições das contagens esperadas para dois cenários: (a) comissão opositora, com a taxa de governismo fixada no primeiro quartil, aproximadamente $48 \%$; (b) comissão governista, com a taxa de governismo fixada no terceiro quartil, aproximadamente $59 \%$.

Legislativa na Câmara dos Deputados" quanto à estrutura de incentivos da produção endógena e compartilhamento de informações no Legislativo ao se considerar a distância de preferências entre os decisores e atores relevantes. Quando levamos em conta a influência do tempo e das especificidades de cada comissão (modelos com efeitos fixos), a região mais oposicionista apresenta maior contagem esperada de projetos de lei e de pareceres da Consultoria, mas com significativa dispersão e sobreposição nas áreas, que ainda assim inclui o valor médio do cenário oposto. Se, por um lado, os resultados relativos à contagem de PLs são mais expressivos do comportamento esperado das próprias 
comissões, os valores obtidos para número de pareceres trazem à tona que a dinâmica informacional e seu contexto estratégico também se relacionam com o trabalho de assessoramento parlamentar desenvolvido pela Conle.

Em termos gerais e a partir desses achados, não é razoável rejeitar a hipótese informacional sobre a demanda aos recursos da estrutura de assessoria legislativa da Câmara dos Deputados pelo seu sistema de comissões permanentes. Antes pelo contrário, a análise empreendida sugere apoio à hipótese de que são as comissões opositoras aquelas que mais utilizam os serviços da Consultoria Legislativa, pois possuem incentivos racionais para produzir e revelar informação crível num contexto de tomada de decisão em que a incerteza é levada em conta. Ou seja, um dos elementos que instrui o comportamento dos atores no Legislativo, sobretudo no âmbito das comissões, e, por conseguinte, a própria organização dos procedimentos e das estruturas que servem à atividade parlamentar, é a necessidade de reduzir a incerteza sobre os resultados das políticas.

\section{CONSIDERAÇÕES FINAIS}

A vitória do modelo de organização legislativa defendido por Mozart Vianna em seu embate com o modelo defendido por Pojo do Rego gerou a convivência de uma assessoria eminentemente voltada para os interesses partidários e de reprodução eleitoral dos parlamentares com uma assessoria essencialmente técnica, cujos membros se percebem como especialistas neutros no desempenho de suas funções. Duas implicações fundamentais daí derivam.

Do ponto de vista estritamente científico, as proposições básicas extraídas da aplicação da teoria informacional ao caso da Câmara dos Deputados são merecedoras de atenção e, longe de esgotadas - seja na elaboração teórica ou no exame empírico - constituem ponto relevante na agenda de pesquisas sobre o Legislativo brasileiro. Nesta análise, vimos que a literatura sobre o Congresso Nacional de forma predominante se desdobra em duas perspectivas: a distributivista e a partidária. Trabalhos desenvolvidos por Santos e Almeida (2005 e 2011) exploram como a lógica informacional encontra-se presente na operação do Legislativo no âmbito do presidencialismo brasileiro quando do exame de deliberação em torno de políticas públicas. O uso de mecanismos institucionais endógenos, como os pedidos de urgência e a escolha de 
relatorias, teria, nesta perspectiva, a função de subsidiar o plenário quando da tomada de decisões. Neste artigo, procuramos debater uma das questões ainda incompletas numa teoria informacional aplicada ao Congresso brasileiro, a saber, de que forma o mesmo se encontra tecnicamente aparelhado para a geração de informações especializadas, bem como a lógica política presente na utilização da Consultoria Legislativa, órgão que expressa de forma mais cabal o conjunto de recursos de expertise à disposição da Câmara dos Deputados.

É relevante notar que tal órgão, diferente da assessoria própria dos mandatos parlamentares, figura como locus privilegiado para avaliar os aspectos informacionais do processo legislativo na Câmara. Não apenas pela qualificação de seu quadro técnico e independência funcional, mas justamente pelo seu potencial em termos de posição estratégica para servir aos decisores cujas preferências distanciam-se do Executivo, como fonte de informação crível sobre aspectos verificáveis das propostas legislativas (hard data). Ou seja, se a lógica informacional encontra aplicação, por exemplo, junto a relatorias e trabalhos das comissões permanentes, com mais razão deve servir para balizar a Consultoria Legislativa. E, na medida em que informação crível sobre os possíveis resultados das políticas configura um bem coletivo do Legislativo, o próprio desenvolvimento dessa espécie de trabalho independente de assessoramento representa um espaço não desprezível para que elementos teóricos informacionais também contribuam para a compreensão do processo legislativo brasileiro. Aqui, mais do que concorrência com abordagens distributivistas ou partidárias, por exemplo, trata-se de complementação.

Nesse sentido, a etapa qualitativa de nossa pesquisa evidenciou diferenças significativas quanto à natureza do trabalho da Conle vis-à-vis os demais tipos de assessoramento ao trabalho dos deputados. Natureza que se revelou eminentemente técnica e neutra, ao contrário das pressões partidárias e individuais evidentes nos casos do secretariado da Mesa e no trabalho da assessoria de lideranças. Na mesma linha, as entrevistas também sugeriram que o trabalho da Conle consiste essencialmente em subsidiar os relatores, responsáveis pela emissão de pareceres em torno de políticas públicas relevantes no conjunto da agenda do Legislativo, sobretudo no contexto das comissões permanentes. Em diálogo com a teoria, portanto, enquanto a assessoria de mandatos individuais atenderia incentivos distributivistas, e a de liderança, os partidários, a Consultoria serve à própria Casa, na produção endógena 
de informações, conforme a estrutura de incentivos institucionais e o contexto político-estratégico que mobilizam seu acionamento, a rigor, pelas comissões.

Na etapa quantitativa de nossa discussão empírica exploramos duas hipóteses derivadas da literatura informacional aplicada à Câmara dos Deputados. A primeira, com base na ideia de que a produção de informações tem custos de oportunidade ligados ao contexto das disputas políticas e das eleições, associa o calendário eleitoral à magnitude do trabalho da Conle. A segunda, fundada na discussão teórica relativa ao "viés" do governo ou de instâncias decisórias no interior do Legislativo em relação ao mediano do plenário, relaciona o perfil das comissões permanentes, opositora versus governista, ao maior ou menor incentivo à demanda por pareceres deste órgão.

Essas duas questões provêm de um esquema analítico basicamente informacional. Produzir informação, especialmente hard data, não é um processo isento de custo, seja para o decisor ou para o agente consultado. Por conta disso, além de outros custos de oportunidade, o tempo torna-se fator importante. Mas buscar informação é tarefa relevante ao decisor quando existirem razões para que os sinais emitidos pelo propositor da política não sejam críveis. Daí que decisores com preferências mais distantes do proponente - como as comissões opositoras têm maiores incentivos para produzir informaçoes alternativas. Por trás de ambas as hipóteses reside o pressuposto de que o legislador decide em condição de incerteza diante de uma estrutura de incentivos institucionais e político-contextuais que lhe permite tomar decisões mais ou menos informadas.

Embora a aproximação empírica tenha limitações por conta da natureza dos dados disponíveis, os testes realizados apoiam as observações teóricas apresentadas neste e em outros trabalhos. Ou seja, tanto a demanda à Consultoria é menor em momentos eleitorais, quanto as comissões opositoras são aquelas que mais utilizam esse órgão técnico de assessoramento legislativo. Isso significa, por um lado, que as restrições de tempo impõem obstáculos ao trabalho de assessoramento técnico (além da própria diminuição do trabalho parlamentar em geral), e que, por outro, os recursos da Consultoria, embora disponíveis para a Casa como um todo, são potencialmente mais acessados por aqueles decisores que têm maiores incentivos para se contrapor ao principal proponente de políticas, o Executivo. Tais nuances também merecem 
atenção, pois alertam que os incentivos informacionais postos ao Legislativo brasileiro não são lineares ou caminham necessariamente de forma progressiva. Não se trata de sempre mais e melhor, em qualquer situação. Ao contrário, a produção endógena de informações se dá num contexto estratégico mais matizado.

Finalmente, do ponto de vista institucional, e não mais somente de uma perspectiva conceitual, o artigo mostrou que o sistema de comissões permanentes do Legislativo possui papel informativo relevante no processo decisório em torno de políticas públicas. Quando as divergências entre o Executivo e maiorias congressuais em torno de uma política forem suficientemente grandes e houver comissão oposicionista motivada a examinar, não se tratando de momentos de "impaciência política", como nos períodos eleitorais, a Câmara dos Deputados possui uma estrutura de assessoria suficiente para se contrapor às recomendações emanadas do Executivo. As implicações para a análise da conjuntura brasileira atual são mais do que evidentes, questão, todavia, que escapa ao propósito do artigo.

(Recebido para publicação em agosto de 2015)

(Reapresentado em agosto de 2016)

(Aprovado para publicação em novembro de 2016) 


\section{NOTAS}

1. Ver Abreu e Dias (1995).

2. Boas revisões da fase inicial desta literatura encontram-se em Limongi (1994) e Shepsle e Weingast (1995).

3. Ver Krehbiel (1991); e Brady e Volden (1998).

4. Ver Figueiredo e Limongi (1999); Pereira e Mueller (2000); Carvalho (2003); Amorim Neto e Santos (2003).

5. Trabalhos como o de Figueiredo e Limongi (1999) e de Pereira e Mueller (2000) são bastante contundentes a respeito, ao afirmarem a preponderância do Executivo sobre os órgãos internos do Legislativo, sobretudo as comissões. Para uma visão um pouco mais matizada, isto é, que detectam influência e relevância de comissões específicas sobre o processo decisório na Câmara, ver Ricci e Lemos (2004) e Santos (2002).

6. Embora o argumento apresentado neste artigo confira destaque ao potencial informacional das comissões permanentes opositoras, tal aspecto está longe de resumir os ganhos resultantes do sistema de comissões, ou mesmo as principais oportunidades estratégicas das oposições. Como aponta Inácio (2009), o plenário também oferece recursos institucionais importantes aos grupos em disputa com a coalizão governativa, destacando-se a hipótese de que o trancamento de pauta por MPs, a partir de 2001, amplia as recompensas dos instrumentos da obstrução e verificação de votações às oposições, deflagrando barganhas sequenciais com o governo.

7. Ver, principalmente, Santos e Almeida (2011).

8. O pressuposto mais usual é que $\omega$ é a realização de uma variável aleatória uniformemente distribuída com suporte em $[0,1]$.

9. É a partir desse aspecto base que tanto o arsenal teórico quanto as aplicações da vertente informacional desenvolveram-se. De início, o modelo de jogo de sinalização e cheap talk de Crawford e Sobel (1982) assume que o decisor desinformado - diante de um contexto de incerteza - tem a opção de "ouvir" a recomendação de um especialista com preferências potencialmente distintas, criando uma estrutura de incentivos para a produção e compartilhamento de informações. Gilligan e Krehbiel (1987) promovem uma espécie de aplicação do modelo ao legislativo americano, enquanto Krehbiel (1991) reúne diversos achados e reflexões dando melhor forma à teoria informacional. Desenvolvimentos mais recentes ampliam o modelo padrão de cheap talk para jogos legislativos ao permitir que o decisor consulte múltiplos conselheiros (Krishna e Morgan, 2001) e ao endogeneizar a produção de informações com custos variáveis (Beniers e Swank, 2004; Dur e Swank, 2005), sofisticando a estrutura de incentivos. Os trabalhos de Santos e Almeida (2009 e 2011) são adaptações não formais dessas indicações teóricas ao contexto da Câmara dos Deputados brasileira, combinadas a esforços empíricos.

10. Ver a respeito Ribas e Silva (2011:17).

11. O secretariado parlamentar é a categoria de servidores que trabalha diretamente ligada aos gabinetes dos parlamentares. São contratados diretamente pelos deputados e podem atuar tanto em Brasília quanto nos estados de origem destes. Uma descrição dessa classe de servidores pode ser encontrada em: http://www2.camara. leg.br/a-camara/conheca/camara-destaca/55a-legislatura/gabinete-parlamen- 
tar/secretariado-parlamentar/informacoesgerais_sobre_osecretariadoparlamentar.

12. Após efetuar entrevistas com mais de quarenta deputados, a pesquisa realizada pela Fundação Getúlio Vargas apontava que a deficiência central no âmbito organizacional da Câmara consistia na ausência de um sistema de informação parlamentar, em outras palavras, na inexistência de assessoria de alto nível, tendo por escopo apoiar o trabalho das comissões técnicas e o trabalho individual do deputado. Embora bastante citado em textos de assessores, não há uma clara referência sobre quando e onde o estudo foi publicado.

13. Ver Souza (2011:54).

14. Área I - Direito Constitucional, Eleitoral, Municipal, Administrativo, Processo Legislativo e Poder Judiciário; Área II - Direito Civil e Processual Civil, Penal e Processual Penal, de Família, do Autor, de Sucessões, Internacional Privado; Área III - Direito Tributário, Tributação; Área IV - Finanças Públicas; Área V - Direito do Trabalho e Processual do Trabalho; Área VI - Direito Agrário e Política Fundiária; Área VII - Sistema Financeiro, Direito Comercial, Econômico, Defesa do Consumidor; Área VIII - Administração Pública; Área IX - Política e Planejamento Econômicos, Desenvolvimento Econômico, Economia Internacional; Área X - Agricultura e Política Rural; Área XI - Meio Ambiente e Direito Ambiental, Organização Territorial, Desenvolvimento Urbano e Regional; Área XII - Recursos Minerais, Hídricos e Energéticos; Área XIII - Desenvolvimento Urbano, Trânsito e Transportes; Área XIV - Comunicação Social, Informática, Telecomunicações, Sistema Postal, Ciência e Tecnologia; Área XV - Educação, Cultura, Desporto, Ciência e Tecnologia; Área XVI Saúde Pública, Sanitarismo; Área XVII - Segurança Pública e Defesa Nacional; Área XVIII - Direito Internacional Público, Relações Internacionais; Área XIX - Ciência Política, Sociologia Política, História, Relações Internacionais; Área XX - Redação e Discurso Parlamentar; Área XXI - Previdência e Direito Previdenciário; Área XXII - Direito Penal, Direito Processual Penal e Procedimentos Investigatórios Parlamentares.

15. Quadro de servidores efetivos no cargo de Consultor, em 20/7/2015, segundo seção de Transparência - Recursos Humanos, do Portal da Câmara dos Deputados.

16. Ver Azevedo (2011:9).

17. A respeito do investimento em capacitação de pessoal, vale a pena consultar o site da Câmara dos Deputados do Centro de Formação em Recursos Humanos da Câmara (Cefor).

18. Por exemplo, é razoável imaginar que a área de direito, com suas diversas ramificações, seja sobrepovoada de assessores, dada a necessidade do órgão parlamentar em dominar a técnica legislativa em praticamente todas as suas manifestações.

19. Embora a hipótese não seja especificamente testada neste artigo no que diz respeito à ativação da Consultoria Legislativa, a ideia por trás dela é relevante para o restante da investigação. É justamente da noção de "viés" na produção de informações sobre a política em debate, decorrente da distância entre preferências entre Executivo e medianos do plenário e das comissões, que se deduzem as possibilidades de ganhos informacionais na consulta a órgãos técnicos. O que recomenda a produção de informação pela comissão ou a adoção de tramitação ordinária, também sugere ganhos com a consulta ao assessoramento legislativo. Essa construção teórica representa um 
dos fundamentos principais da hipótese relativa ao "governismo" ou "oposicionismo" das comissões.

20. Sobre alguns tipos de impaciência político-legislativa (sistêmica, projeto-específica e eleitoral), ver Tsebelis e Money (1997).

21. Difícil distinguir, neste particular, o que é efeito da pressa para decidir daquilo que é custo de oportunidade incorrido pelo parlamentar ao deixar afazeres de campanha e se dedicar às complexidades do processo decisório em políticas públicas. É alta a probabilidade de que ambos os efeitos atuem como incentivos à ação dos representantes. De toda forma, a existência de evidência em favor da redução do trabalho da Consultoria em anos eleitorais não nos permite descartar o efeito pressa, de cunho informacional, como mecanismo importante no acionamento do trabalho da assessoria parlamentar especializada.

22. Na estrutura institucional da Câmara, o principal órgão a iniciar a tramitação e depois definir o destino de uma proposição consiste na Secretaria-Geral da Mesa da Câmara dos Deputados (SG). Por ela passam todas as propostas que exigem decisão pelo Legislativo. A responsabilidade pelo estabelecimento de qual comissão deve ou, como é frequente, quantas e quais comissões devem avaliar o mérito e a adequação de uma política cabe à SG. Importante assinalar que o envio para uma ou mais comissões não é politicamente neutro, pois, quando uma matéria transita por mais de três comissões permanentes, o Regimento pede a criação de uma comissão especial.

23. Pela Comissão de Constituição, Justiça e Cidadania (CCJC) passam todos os projetos que tramitam na Câmara, o que revela sua importância e centralidade. Sem o seu crivo, nada pode ser aprovado, seja em plenário, seja em regime conclusivo nas demais comissões permanentes. Se, de um ponto de vista técnico, cabe à CCJC apreciar tão somente sobre a constitucionalidade e boa técnica legislativa, de outro, é relevante o peso político que um órgão com tal prerrogativa acaba adquirindo no conjunto da atividade legislativa da Câmara.

24. Pela Comissão de Fiscalização Financeira e Controle passam todos os projetos de impacto na arrecadação do Estado, além dos projetos de natureza orçamentária e a averiguação de contas.

25. Foi utilizada a seguinte classificação de equivalência entre Comissões Permanentes e Áreas de Assessoramento: CTASP = Administração Pública; Direito do Trabalho; CAPADR = Agricultura; Direito Agrário $; C C T C I=$ Comunicação $; C D C=$ Finanças e Comércio; CDHM = Ciência Política e Sociologia; Direito Internacional Público e Relações Internacionais; CCJC = Direito Constitucional; Direito Material e Processual; $\mathrm{CFT}=$ Direito Tributário; Finanças Públicas $; \mathrm{CTUR}=$ Economia $; \mathrm{CDEIC}=$ Economia; $\mathrm{CE}=$ Educação e Cultura; CINDRA = Meio Ambiente; CMADS = Meio Ambiente; $\mathrm{CSSF}=$ Previdência; Saúde; $\mathrm{CME}=$ Recursos Minerais; $\mathrm{CSPCCO}=$ Segurança Públi ca; $\mathrm{CVT}=$ Urbanismo e Transporte; $\mathrm{CDU}=$ Urbanismo e Transporte $; \mathrm{CREDN}=$ Direito Internacional Público e Relações Internacionais.

26. É possível que o procedimento de pareamento por áreas temáticas oculte um viés quanto ao acionamento da Conle pelas comissões permanentes, qual seja, que parte dos pareceres seja remetida a comissões especiais, temporárias ou ao plenário. Porém, três pontos minimizam essa possibilidade. Em primeiro lugar, a fase qualitativa da pesquisa, através das entrevistas, indicou, de forma consistente e sistemática, que o trabalho da Consultoria volta-se ao assessoramento das comissões permanentes, 


\section{Fabiano Santos e Júlio Canello}

sendo residual em relação ao demais. Além disso, salvo nos ritos especiais de tramitação legislativa, as proposições são, via de regra, submetidas às comissões permanentes, ou seja, ainda que um trabalho da Conle siga para o plenário, por exemplo, a comissão originalmente competente para debater a matéria é a da área temática. Finalmente, as entrevistas também indicaram que as matérias em trâmite no plenário são mais influenciadas pela assessoria do próprio Relator do que pelo órgão central de Consultoria, o que reafirma o efeito apenas residual desse possível viés.

27. Nesse contexto, para além dos serviços prestados pela Conle, não se pode ignorar os esforços das assessorias dos próprios parlamentares que relatam os projetos e integram as instâncias e até mesmo os recursos e procedimentos ao alcance das Comissões Permanentes para a produção de informação, tais como a realização de Audiências Públicas e a apresentação de estudos, pesquisas e pareceres por agentes e organizações externos à estrutura do Legislativo.

28. Mensuramos o "governismo" dos deputados federais como a proporção de votos nominais em plenário na qual o parlamentar seguiu a orientação do Líder do Governo, em termos absolutos, ou seja, levando em conta as ausências em votações. A taxa foi calculada para cada semestre, entre 2004 e 2011, considerando os políticos que estiveram aptos a votar em mais de $10 \%$ das votações nominais realizadas no período correspondente. $\mathrm{O}$ indicador foi agregado para cada comissão utilizando-se a mediana entre seus membros titulares.

29. Lembrando, contudo, o potencial ruído decorrente da baixa qualidade dos dados quantitativos disponibilizados ao público, suficiente para dificultar inferências seguras. Nesse sentido, nenhum dos resultados apresentados busca testar hipóteses causais de maneira conclusiva. Esta análise pretende, apenas, apresentar apontamentos no sentido da plausibilidade das explicações sugeridas e pela importância de avançar no presente tópico de pesquisa.

30. Os resultados dos modelos estimados estão disponíveis no apêndice on-line deste artigo. 


\section{REFERÊNCIAS BIBLIOGRÁFICAS}

ABREU, Alzira Alves; DIAS, José Luciano. (1995), O Futuro do Congresso Brasileiro. Rio de Janeiro, FGV Editora.

AMORIM NETO, Octavio; SANTOS, Fabiano. (2003), “O Segredo Ineficiente Revisto: O que Propõem e o que Aprovam os Deputados Brasileiros". DADOS - Revista de Ciências Sociais, vol. 46, no 4, pp. 661-697.

AZEVEDO, Luiz Henrique Cascelli. (2011), “Consultoria Legislativa e Assessoramento Institucional: 40 Anos", in Câmara dos Deputados, 40 Anos de Consultoria Legislativa: Consultores Legislativos e Consultores de Orçamento. Brasília, Edições Câmara, Centro de Documentação e Informação.

BENIERS, Klaas J.; SWANK, Otto H. (2004), "On the Composition of Committees". Journal of Law, Economics and Organization, vol. 20, no 2, pp. 353-378.

BRADY, David W.; VOLDEN, Craig. (1998), Revolving Gridlock: Politics and Policy from Carter to Clinton. Colorado, Westview Press.

CARVALHO, Nelson Rojas. (2003), E no Início Eram as Bases: Geografia Política do Voto e Comportamento Legislativo no Brasil. Rio de Janeiro, Revan.

CRAWFORD, Vincent P.; SOBEL, Joel. (1982), “Strategic Information Transmission”. Econometrica, vol. 50, no 6, pp. 1431-1451.

DUR, Robert; SWANK, Otto H. (2005), "Producing and Manipulating Information". The Economic Journal, № 115, pp. 185-199.

FIGUEIREDO, Argelina C.; LIMONGI, Fernando. (1999), Executivo e Legislativo na Nova Ordem Constitucional. Rio de Janeiro, FGV Editora.

GILLIGAN, Thomas W.; KREHBIEL, Keith. (1987), “Collective Decision-Making and Standing Committes: An Informational Rationale for Restrictive Amendment Procedures". Journal of Law, Economics, and Organization, vol. 3, pp. 145-193.

HORTA, Anderson Braga. (2011), “Breve Memória sobre o Assessoramento Legislativo na Câmara dos Deputados", in Câmara dos Deputados, 40 Anos de Consultoria Legislativa: Consultores Legislativos e Consultores de Orçamento. Brasília, Edições Câmara, Centro de Documentação e Informação.

INÁCIO, Magna. (2009), "Mudança Procedimental, Oposições e Obstrução na Câmara dos Deputados", in M. Inácio; L. Rennó (orgs.), Legislativo Brasileiro em Perspectiva Comparada. Belo Horizonte, UFMG Editora.

KREHBIEL, Keith. (1991), Information and Legislative Organization. Ann Arbor, The University of Michigan Press.

KRISHNA, Vijay; MORGAN, John. (2001), "A Model of Expertise". Quarterly Journal of Economics, vol. 116, № 2, pp. 747-775.

LIMONGI, Fernando. (1994), “O Novo Institucionalismo e os Estudos Legislativos: A Literatura Norte-americana Recente". Boletim Informativo e Bibliográfico de Ciências Sociais, no 37, pp. 3-38.

DADOS - Revista de Ciências Sociais, Rio de Janeiro, vol. 59, no 4, 2016 


\section{Fabiano Santos e Júlio Canello}

PAIVA, Mozart Vianna de. (1995), “Assessoramento do Poder Legislativo, Experiência Pessoal e Profissional, Avaliação da Situação Brasileira”, in A. A. de Abreu; J. L. Dias (orgs.), O Futuro do Congresso Brasileiro. Rio de Janeiro, FGV Editora.

PEREIRA, Carlos; MUELLER, Bernardo. (2000), “Uma Teoria da Preponderância do Poder Executivo: O Sistema de Comissões no Legislativo Brasileiro". Revista Brasileira de Ciências Sociais, vol. 15, no 43, pp. 45-68.

REGO, Antonio Carlos Pojo do. (1995), “O Assessoramento do Congresso”, in A. A. de Abreu; J. L. Dias (orgs.), O Futuro do Congresso Brasileiro. Rio de Janeiro, FGV Editora.

RIBAS, Antonio Neuber; SILVA, Paulo Vieira da. (2011), "A Natureza do Assessoramento Legislativo", in Câmara dos Deputados, 40 Anos de Consultoria Legislativa: Consultores Legislativos e Consultores de Orçamento. Brasília, Edições Câmara, Centro de Documentação e Informação.

RICCI, Paolo; LEMOS, Leany Barreiro. (2004), "Produção Legislativa e Preferências Eleitorais na Comissão de Agricultura e Política Rural da Câmara dos Deputados". Revista Brasileira de Ciências Sociais, vol. 19, no 55, pp. 107-130.

SANTOS, Fabiano. (2002), "Partidos e Comissões no Presidencialismo de Coalizão". DADOS - Revista de Ciências Sociais, vol. 45, no 2, pp. 237-264.

; ALMEIDA, Acir. (2005), “Teoria Informacional e a Seleção de Relatores na Câmara dos Deputados". DADOS - Revista de Ciências Sociais, vol. 48, no 4, pp. 693-735.

. (2009), “Urgency Petitions and the Informational Problem in Brazilian Chamber of Deputies". Journal of Politics in Latin America, no 3, pp. 81-110.

(2011), Fundamentos Informacionais do Presidencialismo de Coalizão. Curitiba, Appris.

SHEPSLE, Kenneth A.; WEINGAST, Barry R. (1995), Positive Theories of Congressional Institutions. Ann Arbor, University of Michigan Press.

SOUZA, Célio de. (2011), “A Resolução n. 48, de 1993, e a Consolidação do Assessoramento Legislativo Institucional da Câmara dos Deputados", in Câmara dos Deputados, 40 Anos de Consultoria Legislativa: Consultores Legislativos e Consultores de Orçamento. Brasília, Edições Câmara, Centro de Documentação e Informação.

TSEBELIS, George; MONEY, Jeannette. (1997), Bicameralism. Cambridge, Cambridge University Press. 


\section{RESUMO}

\section{Comissões Permanentes, Estrutura de Assessoramento e o Problema Informacional na Câmara dos Deputados do Brasil}

É quase consenso na literatura sobre o Legislativo no Brasil que faltariam regras e procedimentos capazes de incentivar o desenvolvimento de expertise e capacitação dos parlamentares para a formulação de políticas públicas. Por essa perspectiva, o Congresso ainda estaria por desenvolver mecanismos informacionais no seu modo de atuar. Contudo, é possível detectar, no interior da Câmara dos Deputados, núcleos de excelência, a princípio, capacitados para o exercício de funções de cunho informacional: suas comissões permanentes e a estrutura de assessoria da Câmara (e dentro desta se destacando a Consultoria Legislativa). O artigo analisa especificamente o segundo mecanismo, propondo hipóteses sobre as condições em que o potencial informativo da assessoria é ativado, estabelecendo uma dinâmica informacional em seu modo de atuar e em sua interação com o plenário. A plausibilidade de tais proposições é examinada combinando entrevistas com assessores legislativos à análise quantitativa do fluxo de trabalho das comissões e da própria consultoria.

Palavras-chave: Brasil; Câmara dos Deputados; teoria informacional; Consultoria Legislativa; Comissões Permanentes

\section{ABSTRACT \\ Standing Committees, the Advisory Structure and the Informational Problem in the Brazilian Chamber of Deputies}

Literature on the legislative framework in Brazil is practically unanimous in identifying the lack of regulations and procedures able to incentivize the development of expertise and training among members of parliament for the formulation of public policies, with such a view suggesting that Congress is still to develop information mechanisms as part of its means of operation. It is, however, possible to detect nuclei of excellence within the Chamber of Deputies, initially trained to provide information by means of the standing committees and the Chamber's advisory structure (notably the Legislative Consulting - Consultoria Legislativa). This article focuses on the second mechanism, hypothesizing on the conditions leading to the activation of its informative role and the consequences for both its means of operation and in its interactions with the floor. The plausibility of such propositions is examined, combining interviews with legislative advisors with a quantitative analysis of the workflow in the committees and the Legislative Consulting itself.

Key words: Brazil; Chamber of Deputies; information theory; Legislative Consulting; Standing Committees 


\section{RÉSUMÉ \\ Commissions Permanentes, Structures de Conseil et Problèmes d'Information à la Chambre des Députés Brésilien}

La littérature portant sur le pouvoir législatif brésilien est presque unanime pour dire qu'il manque au Brésil des règles et des procédures en mesure d'encourager le développement de l'expertise et de la formation des parlementaires en matière de formulation des politiques publiques. Sous cette perspective, le Congrès doit encore introduire des mécanismes d'information dans son mode de fonctionnement. Il est néanmoins possible d'identifier au sein de la Chambre des députés des noyaux d'excellence en principe suffisamment formés pour l'exercice de fonctions de conseil et d'information: les commissions permanentes et les structures de conseil de la Chambre (au sein desquelles se distingue le corps des conseillers législatifs - Consultoria Legislativa). Cet article analysera spécifiquement le second mécanisme pour émettre des hypothèses sur les conditions où le potentiel informatif desdites structures est activé pour établir une dynamique informationnelle dans leur mode de fonctionnement et leurs interactions avec l'Assemblée. La plausibilité de ces hypothèses a été vérifiée en combinant des entretiens avec des conseillers législatifs à l'analyse quantitative du flux de travail des commissions et des conseillers eux-mêmes.

Mots-clés: Brésil; Chambre des Députés; théorie informationnelle; Conseillers législatifs; Commissions permanentes

\section{RESUMEN}

\section{Comisiones Permanentes, Estructura de Asesoramiento y el Problema} Informacional en la Cámara de los Diputados Brasileña

Es casi un consenso en la literatura sobre el Legislativo en Brasil que faltan reglas y procedimientos capaces de incentivar el desarrollo de expertise y capacitación de los parlamentares para la formulación de políticas públicas. Desde esta perspectiva, el Congreso todavía estaría por desarrollar mecanismos informacionales en su modo de actuar. Sin embargo, es posible detectar al interior de la Cámara de los Diputados núcleos de excelencia, inicialmente capacitados para el ejercicio de funciones de carácter informacional: sus comisiones permanentes y la estructura de asesoramiento de la Cámara (destacándose dentro de esta la Consultoría Legislativa). El artículo analiza específicamente el segundo mecanismo y propone hipótesis sobre las condiciones en que se activa el potencial informativo del asesoramiento, estableciendo una dinámica informacional en su modo de actuar y en su interacción con el plenario. La plausibilidad de dichas propuestas es examinada combinando entrevistas con asesores legislativos y el análisis cuantitativo del flujo de trabajo de las comisiones y de la misma consultoría.

Palabras clave: Brasil; Cámara de los Diputados; teoría informacional; Consultoría Legislativa; Comisiones Permanentes 